\title{
Planning for Uganda's Urbanization ${ }^{1}$
}

\section{Introduction}

1. Uganda has started its journey into urbanization and economic development. The pace of urbanization is picking up - currently at $4.5 \%$ per year, and likely to accelerate with rising incomes. The economic benefits from urban growth will come from exploiting economies of scale and agglomeration and by increasing fluidity in factor markets that enable substitution between land and non land inputs. Uganda's urban transformation is occurring in a period of particular flux - a changing climate is likely to adversely influence rainfed agriculture, which will have bearing on the prospects of small towns that serve as interlocutors with the rural economy. At the other end, closer economic integration in East Africa will increase the reach of the country's largest metropolis, but place it in direct competition with other metropolises in the region. As prices of tradables converge in an open economy, considerable thought and effort will be needed to reduce the prices of non tradable services that can help maintain economic competitiveness. Policymakers - both at the national and local levels - need to see themselves as change managers who encourage flexibility in how Uganda's towns and cities respond to emerging needs of business and households. Planning ahead is important, but not locking settlements into today's market needs becomes even more important.

2. What are policy priorities to harness economic and social aims from urbanization? This policy note is organized in three sections to answer this question. The first section provides stylized facts on the pace, form and efficiency of Uganda's urban transformation. Section 2 identifies how land policies, urban planning and transport constraints, and housing shortages are choking urbanization and the economy. Section 3 lays out a framework for prioritizing and sequencing urbanization policies. A statistical annex is also provided at the end.

\section{Urbanization and the Economy}

\subsection{Pace and magnitude of urbanization}

3. Rapid urbanization is one of the most striking features of economic development. Developing countries are urbanizing at rates similar to what developed countries experienced about a century ago. On average, today's developed countries increased their urban shares by 7.7 percentage points between 1880 and 1900; today's developing countries have seen urban share increases of 8 percentage points between 1985 and $2005 .{ }^{2}$ Similarly, urbanization is taking off in Uganda where urbanization is estimated at around 13 percent and urban growth rates are around $4.5 \%$ per year and

\footnotetext{
${ }^{1}$ This note has been prepared by Somik Lall drawing on inputs from the Inclusive growth team including Martin Onyach-Olaa(AFTUW), Frank Byamugisha(AFTAR), and Clarence Tsimponkenge (AFTP2).

${ }^{2}$ World Development Report (2009), Reshaping Economic Geography.
} 
projected to increase further. The urban population projected to increase from 13.3 million in 2010 to 20 million in 2030. ${ }^{3}$ International evidence highlights that urbanization proceeds slowly at initial stages of economic development, accelerates (in the stage where countries classified as middle income) and slows down at high levels of income. In this context, Uganda's urban deluge is yet to come. ${ }^{4}$ Uganda's urban shares are still low relative to its neighbors, though there appears to be a consistent link between increasing incomes and changes in urban shares (figure 1).

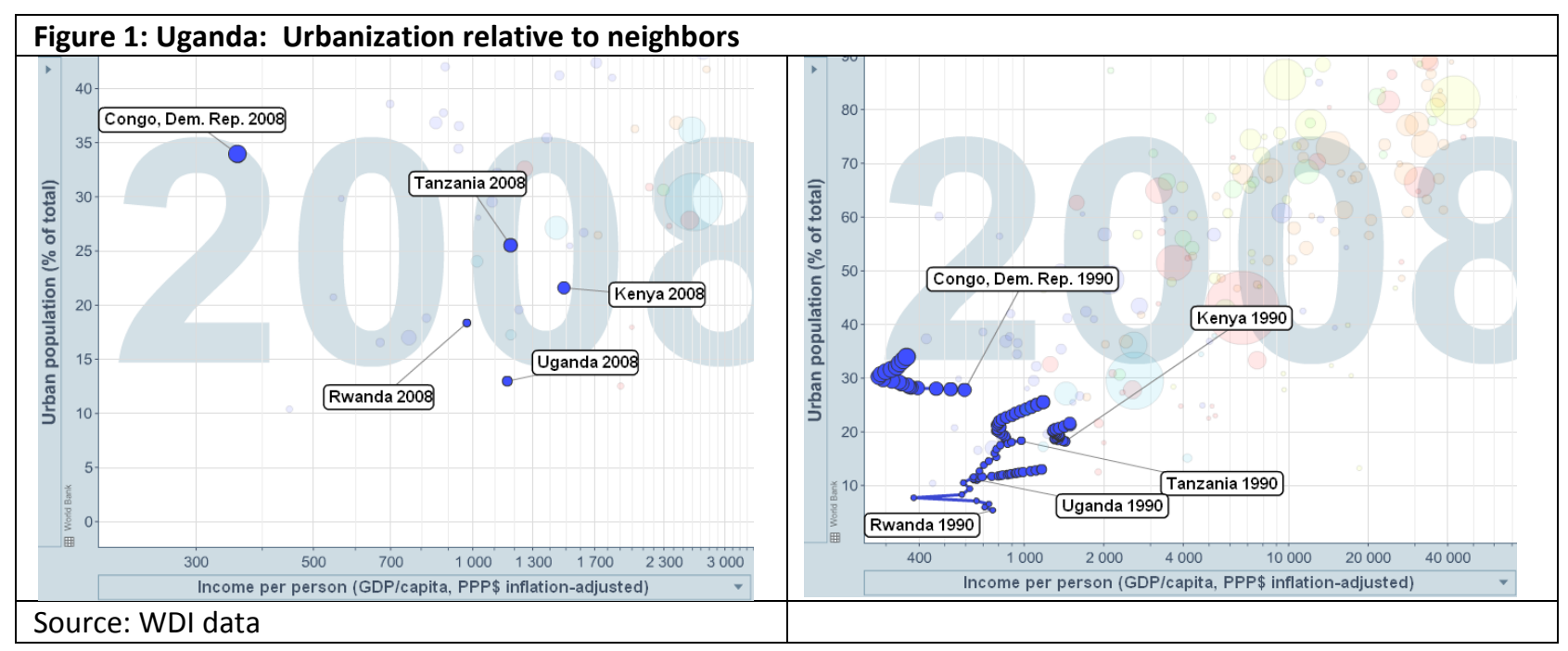

4. Urbanization rates in Uganda are higher than official estimates if one considers an alternate measure - the Agglomeration Index, which considers density, urban size and proximity to the urban center. In fact, this can be thought of as the shadow of the core urban area - with vibrant economic and social interactions with the urban core. The agglomeration index does not use statistical definitions of 'urban areas' - it instead uses three indicators to estimate the level of urban concentration in a country or region - population density, the population size of large urban centers, and travel time to the nearest such urban center. ${ }^{5}$ The agglomeration index is the ratio of the population in the agglomeration area to the total population of the country or region of interest. Using this index, Uganda's urbanization moves up from 13 percent to 25 percent using proximity to cities of 50,000 people; however the index drops to 14 percent if cities of 100,000 or more people are considered (figure 2).

5. A similar pattern is seen in neighboring Kenya, where urbanization is 20 percent using statistical definitions, but increases to 28 percent using the AI using a city size cutoff of 50000; but it drops to 22 percent when the city size cutoff is set at 100,000 people. In contrast, official statistical estimates are higher than the AI for Tanzania, Rwanda and DRC. In DRC for instance, official estimates suggest urbanization of 30 percent compared with the AI estimate of 25 percent. The important point is that the availability and quality of the transport network is likely to have considerable bearing on the extent of

\footnotetext{
${ }^{3}$ World Urbanization Prospects, 2009 revision

${ }^{4}$ The underlying rationale behind this transformation is that at low levels of incomes, most of the labor force is employed in agriculture at subsistence levels. Trade between urban and rural areas is determined by demand for food by the small urban population and demand for urban goods by the rural population. At low incomes, large proportions of income are spent on food with limited demand for urban goods. As incomes rise - possibly due to technological changes in agriculture, the proportion of income spent on food declines and demand for other goods increases. This increases the demand for non food goods as well as demand for labor in urban areas.

${ }^{5}$ Uchida and Nelson 2010
} 
urban interactions. Dense settlements in close proximity but without transport connectivity would have fewer interactions in comparison with better connected but further settlements.

Zooming in within Uganda, the AI is estimated to have increased 7 percentage points between 2002 and 2010 (figure 3). The AI is highest in the central region (54 percent in 2010) and growing rapidly in the Eastern region (11.5 percent points). In 2010, the Western region is the least agglomerated and had the slowest pace of urbanization. ${ }^{6}$
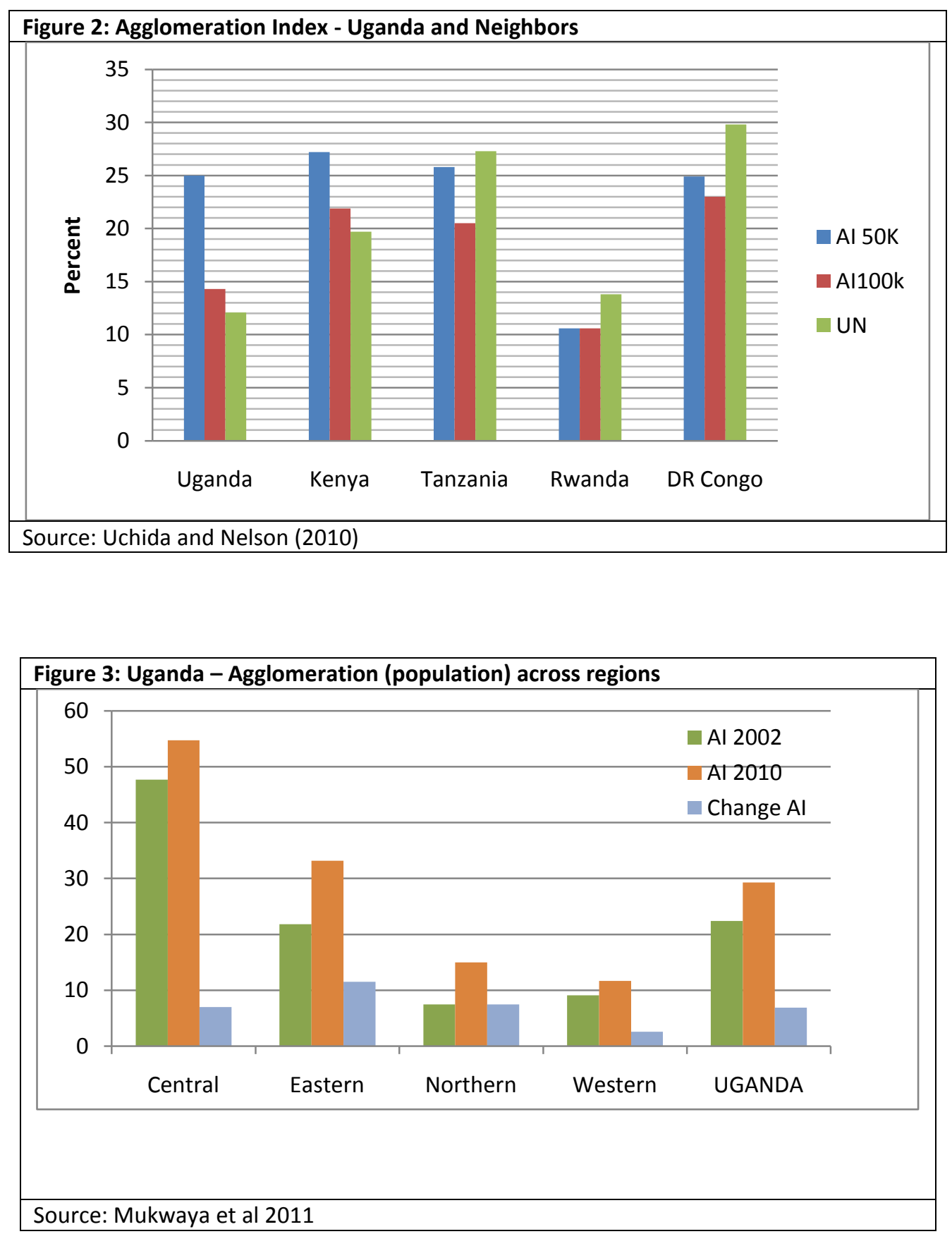
${ }^{6}$ The Al uses a city population cutoff of 50,000. Important to note that transport connectivity is measured by
design definitions of road quality and does not take into account actual road quality or traffic volumes 
6. Urbanization is driven by natural population growth, rural urban migration, and land use reclassification. In principle, rapid population growth is not a necessary condition for rapid urbanization - in fact urbanization can proceed with zero population growth. High fertility is contributing to in situ growth, but new evidence shows that fertility in urban areas - especially in Kampala - is lower, and the number of children is closer to the desired one. ${ }^{7}$ However, the move to cities - rural urban migration has been a key source of urban growth and has been a large part of policy discussions in developing countries. The underlying economic logic is that the migrant is a rational actor seeking to reduce the observed wage differential between his/her rural wage and the prevailing urban wage. In this logic, it is important to adjust the rural-urban nominal wage differential for cost of living differences and other (dis)amenities including congestion and pollution. In fact, poor living conditions in urban areas would reduce the real wage differential.

7. People are mobile in Uganda, but move short distances. While 25 percent of the working age population has been a migrant at some point, most of the movement is within the same district. Less than 40 percent of migrants - and only 10 percent of the overall population-move to another district. And majority of movement within and between districts is from one rural area to another - not to urban areas (it is not clear if these rural areas are adjacent to urban area). ${ }^{8}$ The search of arable land influences migration in Uganda's predominantly agrarian economy where differences in soil quality, land tenure and access to markets matter have considerable bearing on where people want to live. In addition, the flight from conflict has also motivated household decisions to move. The country's civil conflict has displacement many Northerners where 70 percent migrants report insecurity is the leading factor driving migration -- (with 70 percent). In the other three regions, jobs, education and marriage are leading reasons for moving.

8. The move to cities is welfare enhancing. A simulation exercise based on econometric analysis of UNHS data for 2005/06 shows that similar households (size, composition, education) do better when they migrate to urban areas, and generally intra-district migrant households to do better than inter-district households in the receiving district. ${ }^{9}$ One reasonable explanation for this finding is that households that move, but stay within their district of origin, will know the customs, practices, languages, and perhaps even the job market better than "immigrants" from a neighboring district. Furthermore, intra-district migrant households may have closer ties (e.g. a larger network at their destination) than inter-district migrant households because they are more likely to have family or kin living within the same district. These findings also help explain the observation made earlier that the majority of internal migration in Uganda is within the same district rather than between districts.

9. Urban expansion through reclassification of land use from rural to urban has become an important contributor to the urbanization process. In fact, cities across the world are rapidly growing at their edges, surrounding and transforming villages and farmlands. Consider Kampala, which has grown from an administrative township of $0.7 \mathrm{sq} \mathrm{km}$ in 1902 to over $195 \mathrm{sq} \mathrm{km}$ by 1968. Spatial expansion was possible by annexing adjacent townships and rural areas. Now sprawling across $839 \mathrm{sq} \mathrm{km}$, Metropolitan Kampala is continuously converting the rural landscape into urban uses. ${ }^{10}$

\footnotetext{
${ }^{7}$ World Bank (2011) Demography and Economic Growth in Uganda. draft

${ }^{8}$ Koola and Ozden (2010), based on 2005/06 UNHS

${ }^{9}$ Koola and Ozden (2010), based on 2005/06 UNHS

${ }^{10}$ Nyakaana, Sengendo et al. 2004
} 
10. The process of urban expansion is not unique to Uganda or the Kampala Metropolitan Area. Figure 4 shows Kampala's spatial expansion between 1995 and 2001 where suburban built up area has come up on previously open rural space. Urban expansion - measured by the change in built up area is around 6 percent annually, which is faster than either the regional or global pace of urban expansion. However, average densities have declined much slower -- at around 2 percent annually (suggesting redevelopment within the city), which is faster than regional trends but in line with what is happening globally. This process of urban expansion or sprawl will accelerate as incomes rise and people demand larger homes (which can be developed at the city's periphery) and afford cars for comfortable commuting.

11. Beyond pure spatial expansion, administrative reclassifications also influence the pace and magnitude of urbanization. The Ministry of Local Government classifies Gazette cities, municipalities and town councils as urban areas and the Local Government (LG) Act CAP 243 empowers the ministry to declare an area urban if it satisfies the following criteria $^{11}$ : a minimum 25,000 people for town council; 100,000 people for municipality; and 500,000 people for a city; has a master plan for land use; has available water sources and is able to meet the cost of providing services. In addition, the local government act declares all district headquarters as towns. There has been a proliferation of new districts over the past 25 years (by carving out parts of existing districts) -- from 35 in 1986 to 45 in 1998 and 112 in 2010 - and the new district headquarters are automatically gazetted as town councils reclassifying the population urban.

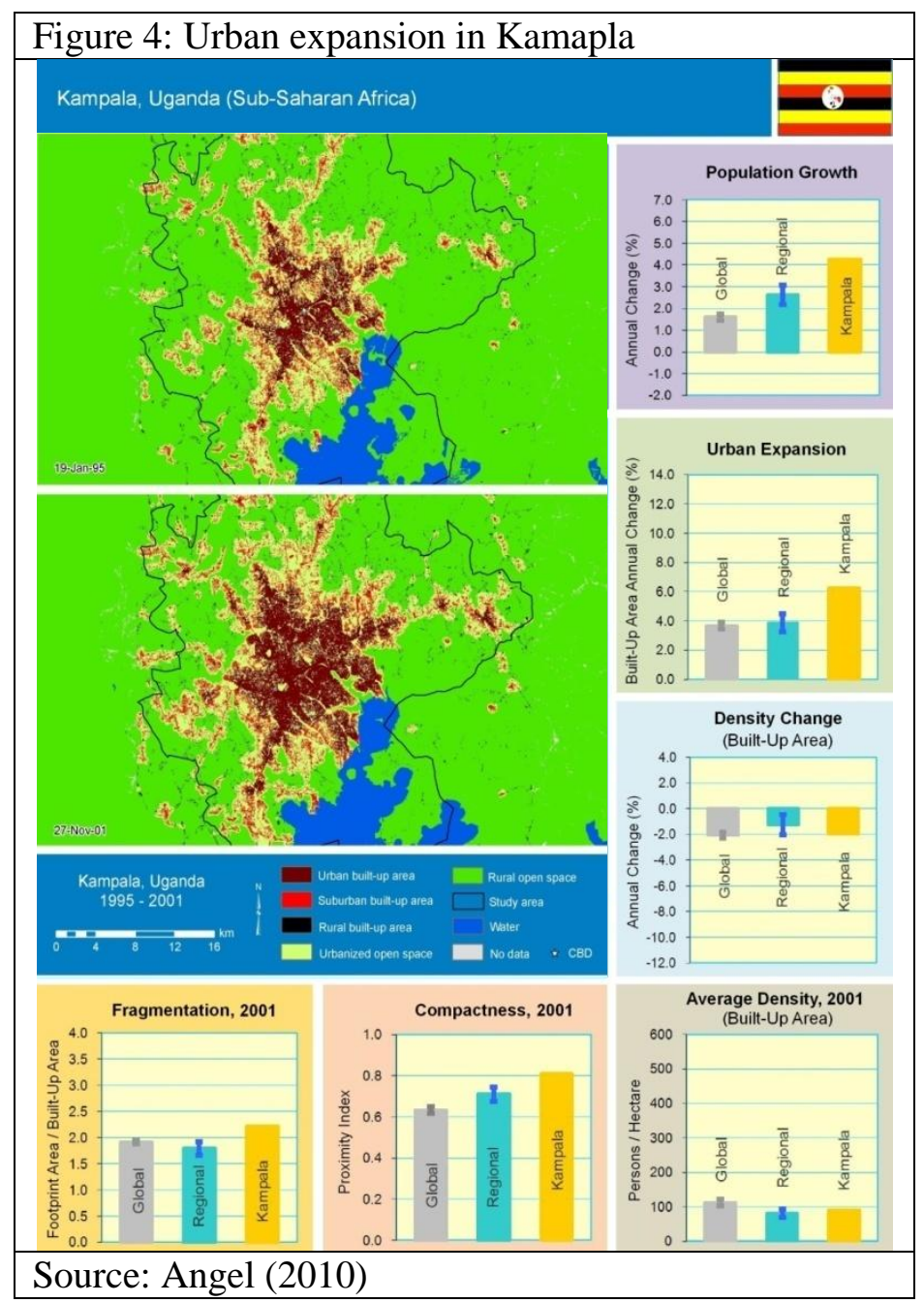

\footnotetext{
${ }^{11}$ In 2010 Parliament has approved the creation of additional nine municipalities although some may not meet all the criteria. The nine Municipalities which became effective Jul 1, 2010 are Hoima, Masindi, Kasese, Busheyi/Ishaka, Ntungamo, Busia, Iganga, Mukono and Rukungiri.
} 


\subsection{Portfolio of cities}

12. Zooming in from the urbanization process to the texture of urban growth - why do some Ugandan cities do better than others at attracting people and nurturing economic activities? Why is Kampala so big? And why are city sizes not equalizing over time? Home to 1.6 million, Kampala dominates the urban landscape, accounting for one-third of Uganda's urban population. The next largest town is Kira with 179,000 located barely $4 \mathrm{kms}$ from Kampala's CBD ${ }^{12}$. The Northern cities of Gulu and Lira are two other cities with more than 100,000 people (figure 5). The skewed distribution of city sizes is of considerable concern to policymakers who would like to stimulate growth in small and medium sized cities. However, this pattern of city sizes is not an outlier, but an empirical regularity across countries and over time.

13. The distribution of large, medium and

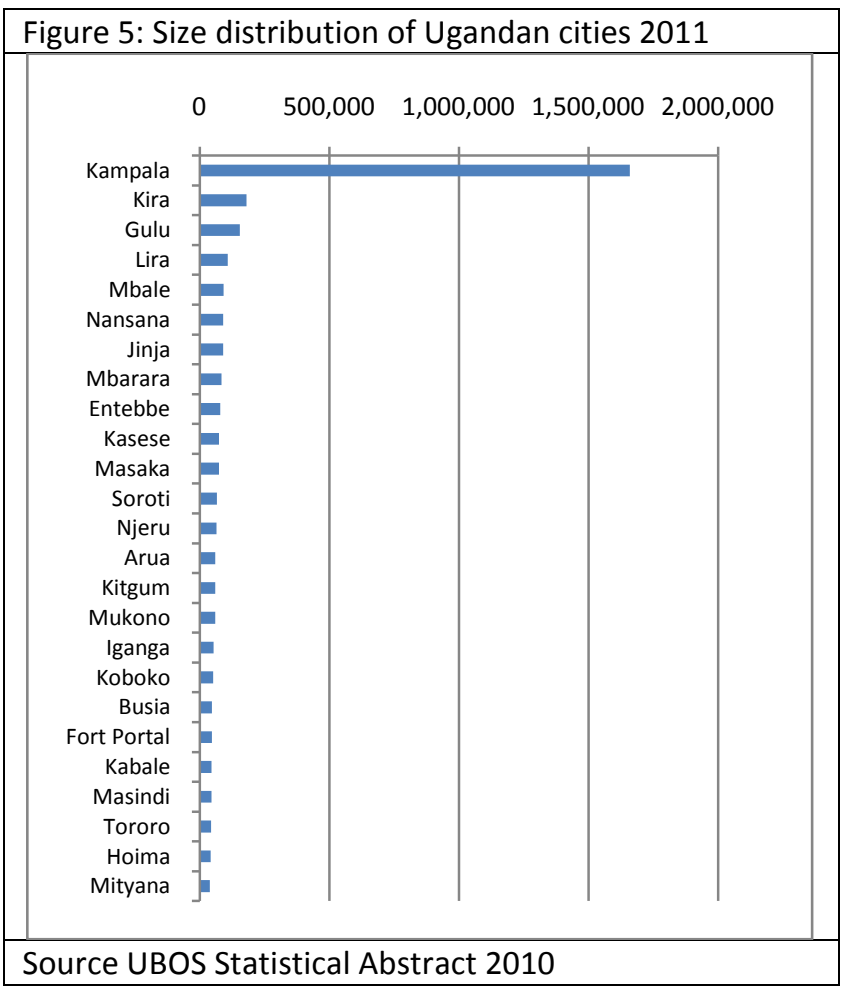

small towns is typically dictated by the distribution of economic activities. The number and distribution of small towns is particularly linked with the level and distribution of agriculture activity. The hierarchy of economies of scale found in the manufacture of different products, along with the agglomeration economies then influences the hierarchy of the size of settlements. In this context, each type and size of urban settlements has its own unique function. And these functions tend to be broadly complementary to each other and not substitutes. The alternative to a large city is another large city, not a small town. The kind of economic activities that give rise to a big city - high end manufacturing and services, transportation nodes, government centers, and financial centers (generating urbanization and localization economies) - if displaced will merely give rise to other big cities, not a bunch of small towns. Activities in small towns are related more to the demand of the agriculture hinterland and rely more on scale economies at the level of the plant. The more prosperous the agricultural hinterland, the more demand for urban services.

14. In fact, the size distribution of cities is fairly stable and tends to follow a power law (called Zipfs law). Ranking the populations size of cities in a country and calculating the natural logarithm of the rank and of the city population will generate a log-linear graph - the rank size distribution. Figure 6 plots the rank size distribution for Uganda, and compares with neighboring Kenya and Tanzania. What is evident that a wide range of city sizes coexist - not only the dominant primate cities or a group of cities of similar size. The challenge is to enable all parts of the urban portfolio to deliver their appropriate economic functions.

\footnotetext{
${ }^{12}$ In fact under the new Kampala City Metropolitan Planning Authority, Kira and Nansana are part of the new Kampala Metropolitan Area.
} 


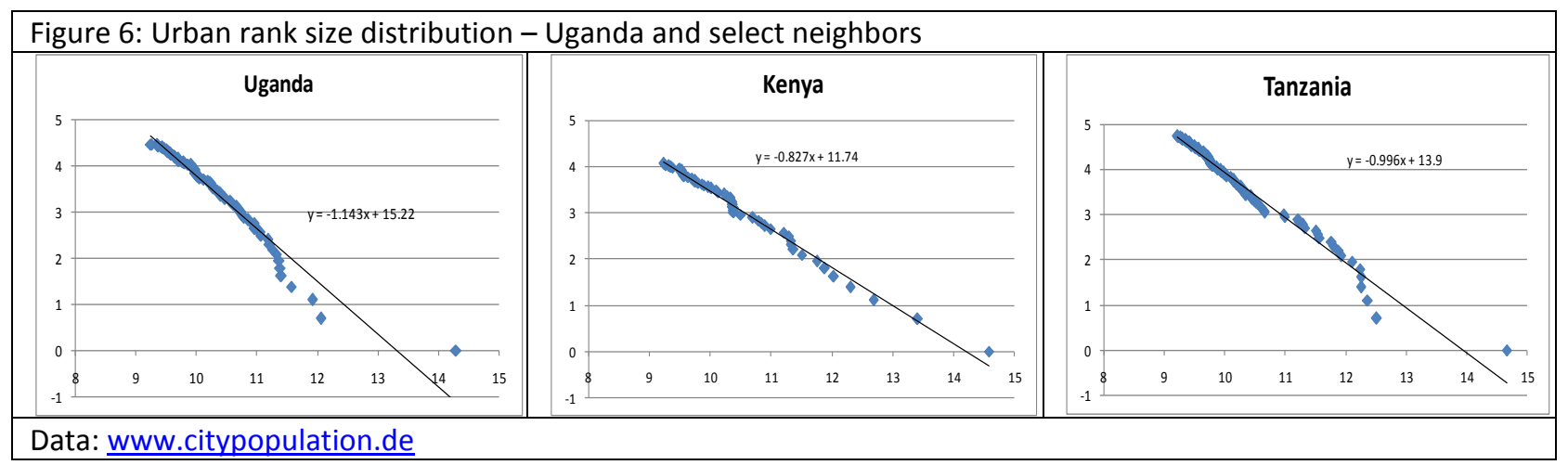

15. Uganda's urban portfolio is dominated by Kampala, which accounts for over 35 percent of the country's urban population. Kampala's primacy is not an outlier - when compared with other countries in Africa (or low income countries in general). In 2007, 22.5 percent of Ethiopia's urban population lived in Addis Ababa and the city was more than ten times larger than the second largest city. Nairobi holds 38 percent of all Kenyan urban dwellers and is 3.7 times the size of Mombasa. Antananarivo's 1.69 million is 8.5 times the second largest city in Madagascar. Mogadishu holds 46 percent of all urban Somalis, and Dar es Salaam 29 percent, Kigali 48.6 percent and Asmara 64.0 percent respectively of their nation's urban dwellers. Urban primacy is widespread in Africa.

\subsubsection{Is Kampala too big?}

16. A cursory look at figure 6 would suggest that Kampala is larger than what the rank size distribution would predict. This is even worse when Kampala is considered in its new definition as the Kampala metropolitan area. But answering question of whether Kampala is too big is not straightforward. First, consider that Kampala is the economic (and political) capital of a small landlocked country thereby limiting the markets that the primate city can serve. Recent work by Paul Collier and Tony Venables shows that Africa's political fragmentation has hurt city size and productivity. As small countries generally have smaller cities, some of the productivity benefits from city size are foregone. ${ }^{13}$ Econometric analysis shows that country area and population are highly significant drivers of city size and that a merger of two similar size countries - i.e. a doubling of population and area - would lead to a $75 \%$ increase in the size of the largest city. As a heuristic, consider the merger of 10 countries, in each of which the largest city has 3 million people. Based on Collier and Venables estimates, the largest city in the combined country will have 19 million people, and a size distribution of city populations that drastically declines for other towns $(19,9.5,6.3,4.7,3.8,3.1,2.7,2.4$ and so on $)$.

17. And this illustration has bearing when the East African Community integrates further, helping Kampala serve a larger economy. The extent to which Kampala grows in response to regional integration will depend on how it well provides a range of amenities and services that an integrated economy will desire. As such the question on Kampala's optimal size is not very useful - but it is more useful to ask if

${ }^{13}$ Collier and Venables 2007 
the metropolis is serving the needs of its firms and households and is it flexible to compete with similar metropolises in the region. Getting urban function right will guide city size.

\subsubsection{Economic role of cities}

18. Economic benefits from urban growth come from exploiting economies of scale and agglomeration and enabling substitution between land and non land inputs. The link between urbanization and economic growth is based on the propensity of non agriculture activities - manufacturing and services - to concentrate in urban areas. Why? Non agriculture activities respond to the size and density of a settlement. As agriculture is land intensive, there is limited scope for a large number of people to concentrate in one settlement. Even though some degree of substitution between land and capital as well as land and labor is possible, its scope is limited compared with manufacturing and services. For manufacturing, capital can substitute land by building high rise factories or by designing processes where use of land is minimized. And services can be carried out in buildings on any size - further increasing the substitution of land by capital. In addition, the

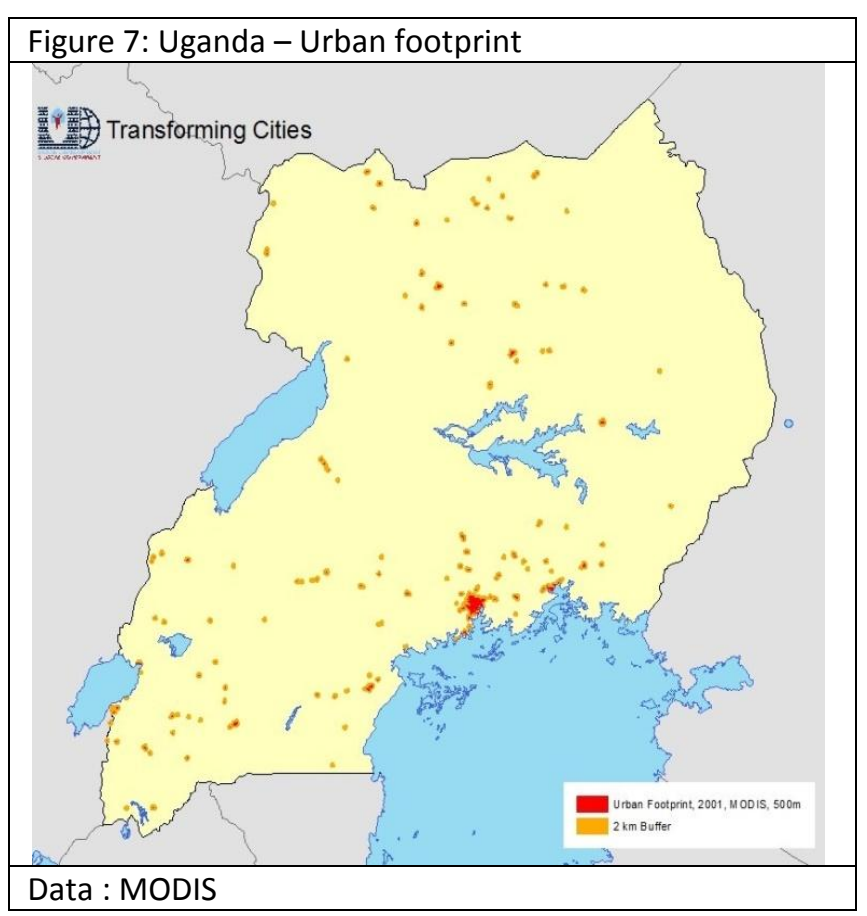
presence of scale and agglomeration economies increases likelihood of the spatial concentration of industry and services. The functioning of industries require complementary services such as banking and finance as well as proximity to other manufacturing facilities for procuring inputs as well as selling intermediate products. Similarly for many retail and business services, a minimum population catchment is needed for profitability (inventories in retail trade and consumers for financial services). Hence, the combination of scale and agglomeration economies and comparatively high non land- land substitution elasticities in industry and services enhance gains from urbanization.

19. Uganda has a small urban footprint (figure 7), dominated by the corridor that connects Kampala with neighboring cities such as Kira, Nansana and Entebbe and Jinja in the East. In fact by 2001, 70\% of the country's 12,000 manufacturing plants with 5 or more employees were clustered around Kampala and the regional transport corridor (figure 8). In fact, the Herfindahl - Hirschman index across industries shows a high degree of spatial concentration (ranges between 0 and 1, 1 is extreme concentration) - and is higher in business services (finance and insurance) relative to manufacturing (figure 9 and Annex Table 1). An alternate measure on industry concentration - the Duranton Overman index also shows high degree of spatial concentration - with the printing and publishing sector being the most concentrated (see box 1). 
20. An econometric analysis of manufacturing location decisions highlights that urbanization economies are valued the most when businesses decide where to locate production facilities. ${ }^{14}$ As discussed above, these include information sharing, process and product innovation as well as producer amenities such as business services, finance, logistics, banking, advertising, and legal services. At this stage of Uganda's development, the range of supporting producer and consumer amenities valued by firms are only found in a few cities (districts). A location quotient measuring the relative specialization of a city in specific industries (defined as a ratio of a location's share of an industry's employment relative to the industry's share of national employment) shows that Kampala is disproportionately represented in most producer amenities (Table 1). Values above (less than) one indicate that the location is relatively more (less) specialized in the specific industry vis-a-vis the national average. Its representation in real estate and business services is 11 times overall industry representation across districts, and 20 times for transport services. Similarly, Kampala has high location quotients in health services and hotels. In contrast, most districts (only a sample reported here) have low levels of specialization in most economic activities.

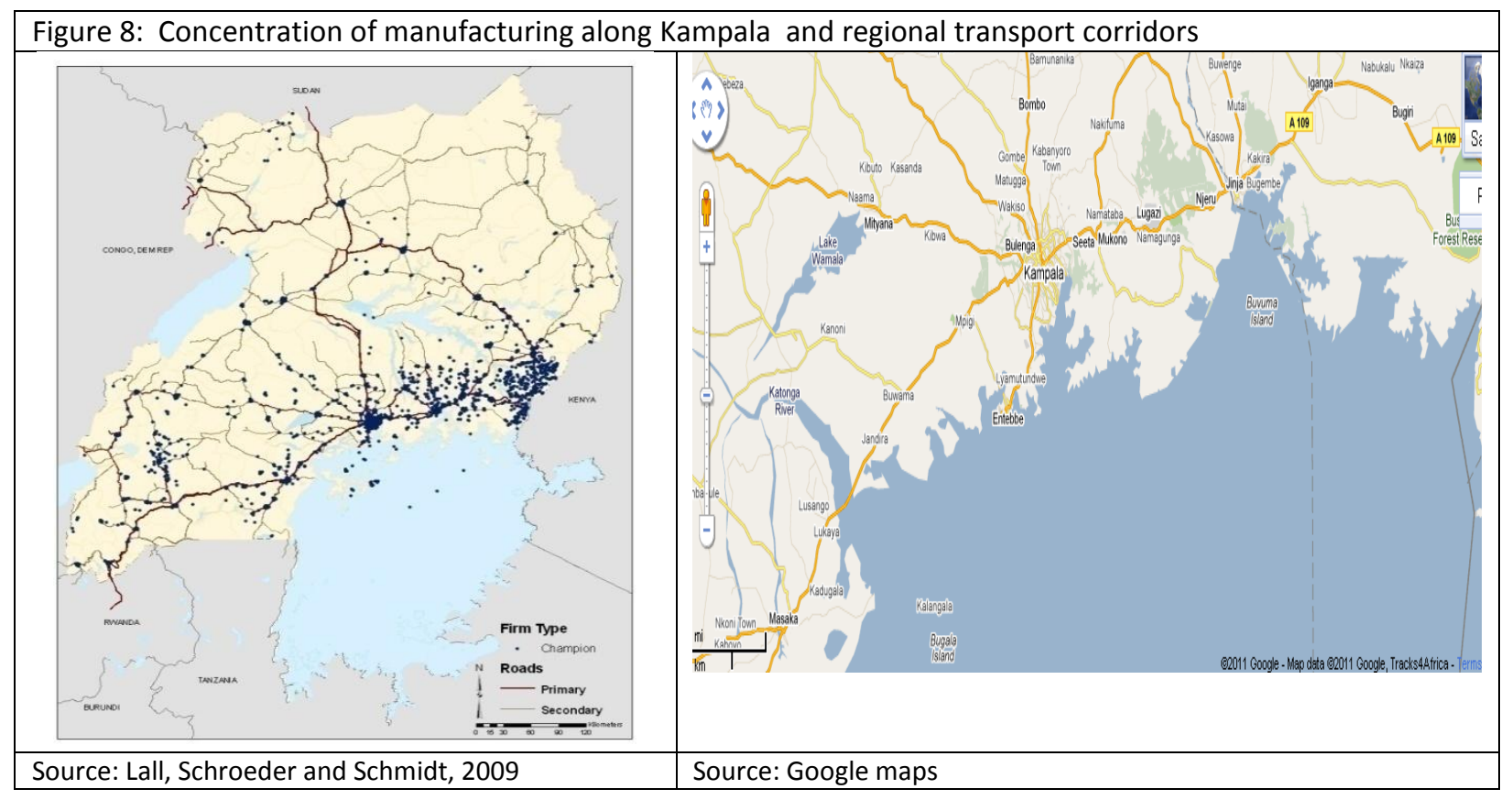

${ }^{14}$ Lall, Schroeder and Schmidt 2009 


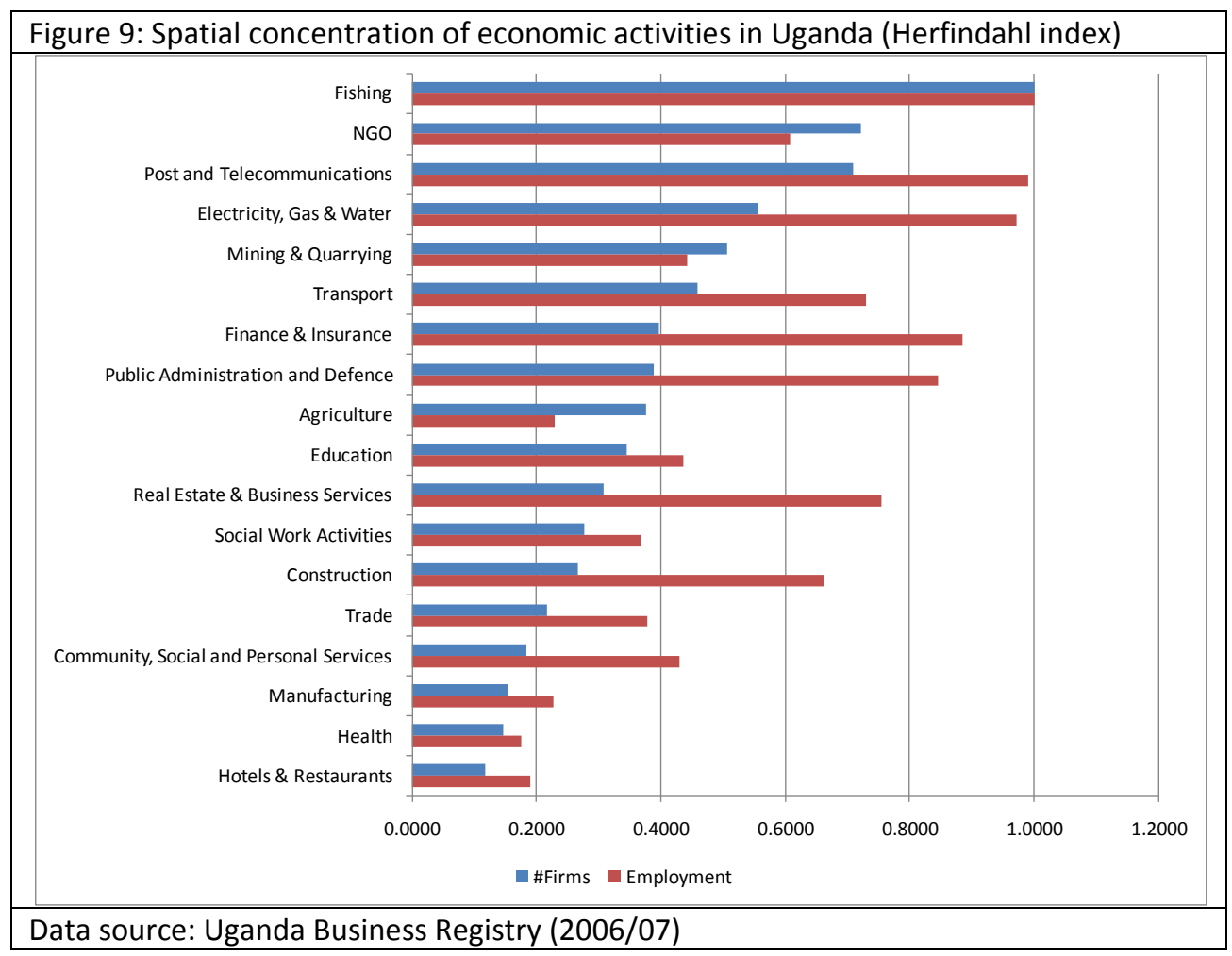

\begin{tabular}{|c|c|c|c|c|c|c|c|c|}
\hline District & Health & $\begin{array}{l}\text { Hotels \& } \\
\text { Restauran } \\
\text { ts }\end{array}$ & $\begin{array}{l}\text { Manufact } \\
\text { uring }\end{array}$ & $\begin{array}{l}\text { Real } \\
\text { Estate \& } \\
\text { Business } \\
\text { Services }\end{array}$ & $\begin{array}{l}\text { Social } \\
\text { Work } \\
\text { Activities }\end{array}$ & Trade & Transport & Total \\
\hline KALANGAL & 0.0 & 0.1 & 0.0 & 0.0 & & 0.1 & 0.1 & 0.0 \\
\hline KAMPALA & 8.9 & 6.6 & 1.4 & 11.0 & 64.4 & 5.9 & 20.3 & 0.5 \\
\hline MASAKA & 1.4 & 0.4 & 0.0 & 0.0 & 1.0 & 0.2 & & 0.0 \\
\hline MPIGI & 0.4 & 0.0 & 0.0 & & & 0.0 & & 0.0 \\
\hline MUBENDE & 0.1 & 0.1 & 0.1 & 0.0 & & 0.1 & & 0.0 \\
\hline MUKONO & 1.2 & 0.3 & 0.3 & 0.1 & 4.8 & 0.1 & & 0.1 \\
\hline WAKISO & 0.7 & 1.1 & 0.2 & 0.1 & 1.9 & 0.3 & 0.8 & 0.1 \\
\hline IGANGA & 0.1 & 0.1 & 0.0 & 0.1 & 2.0 & 0.1 & & 0.0 \\
\hline JINJA & 0.6 & 1.2 & 0.4 & 0.5 & & 0.4 & 0.2 & 0.1 \\
\hline MBALE & 0.6 & 1.3 & 0.0 & 0.2 & & 0.1 & 0.0 & 0.0 \\
\hline TORORO & 0.2 & 0.5 & 0.1 & 0.1 & & 0.1 & 0.1 & 0.0 \\
\hline GULU & 2.3 & 0.4 & 0.0 & 0.2 & & 0.1 & 0.2 & 0.0 \\
\hline LIRA & 0.0 & 0.2 & 0.0 & 0.0 & 1.2 & 0.2 & 0.4 & 0.0 \\
\hline
\end{tabular}




\subsubsection{Box 1: A spatially detailed measure of industry concentration - the Duranton Overman index}

Giles Duranton and Henry Overman - well known economic geographers - have developed a methodology to measure industry localization/ clustering. Their methodology is based on a point pattern approach where physical distances between plants are used to measure the extent to clustering. A potential advantage of this measure is that indicators based on administrative classifications are sensitive to the spatial scale of measurement. Thus, measures utilizing fairly aggregate spatial data may overstate the extent of clustering. For the United Kingdom, Duranton and Overman show that a distance-based measure measuring localization shows lower industrial clustering compared to other measures, such as that developed by Glenn Ellison and Edward Glaeser (EG). If the EG index is used, 94 percent of UK industries show clustering -- are localized; however, the distance measure shows that only 51 percent of industries in the United Kingdom are localized and 26 percent are dispersed.

If an industry is concentrated, the plant to plant distances will be less for firms in that industry than for a randomly chosen firm from the economy at large. The index is computed in two phases: (a) calculate the distribution of inter plant distances in an industry and (b) compare actual distribution with a random assignment of the chosen industry's firms across all manufacturing firm locations (generating $95 \%$ and $99 \%$ confidence bands based on 1000 randomizations). If for a particular industry, the actual distribution is (a) above confidence bands: significant clustering than overall manufacturing, (b) within confidence bands: about as distributed as overall manufacturing, and (c) below confidence bands: more spread out than overall manufacturing. As geo referenced data on plant location are necessary, there are only a handful of developing countries where this measure has been implemented.

In Uganda, the national business registry provides a comprehensive listing of all establishments in the country. A total of 165,000 establishments are included in this database for 2001. For each establishment, we know the physical location (measured by a GPS system), four digit industrial classification, year that it started operations, and number of employees. The GPS coordinates provide a unique location identifier (latitude and longitude) for each establishment, within an accuracy of ten to fifteen meters.

\section{Box Figure: Duranton Overman Industry Localization Measures for Uganda}

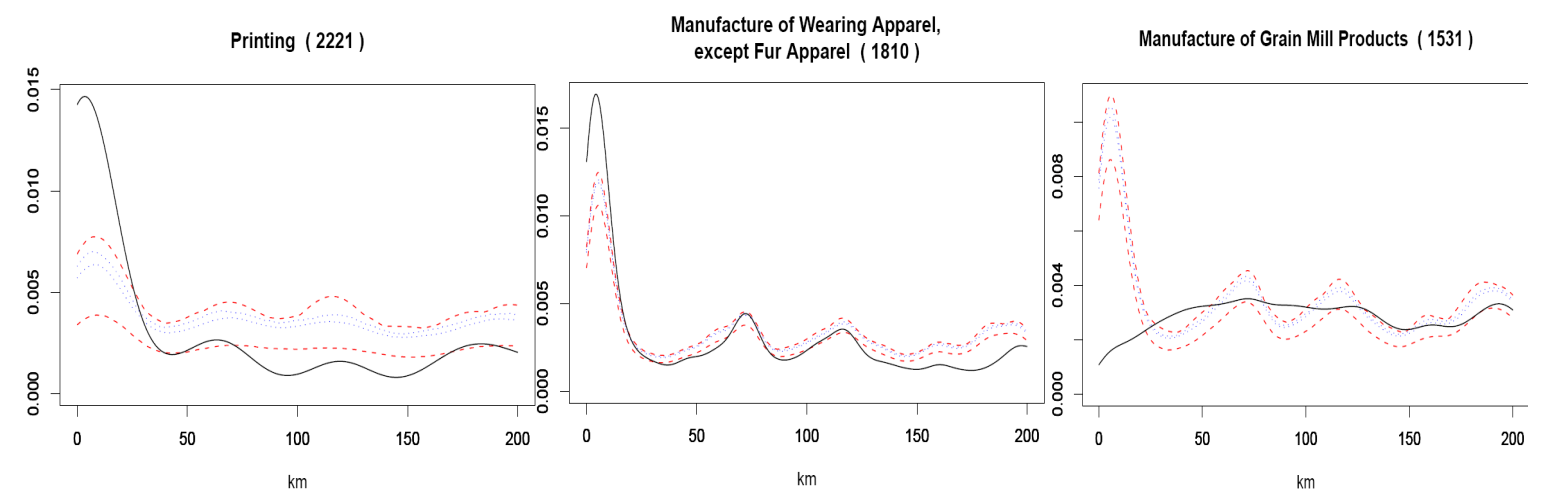

The figure above plots the distribution of inter firm distances and the confidence bands (in red) for three industry sectors - Printing, wearing apparel, and grain milling. Printing is the most concentrated sector with an average inter-plant distance of 1.8 kilometers. The figure above shows that the peak of the actual distribution is much higher that the confidence bands at short distances. Wearing apparel is also clustered at short distances - but there are a couple of "spikes" at higher distances, suggesting that smaller clusters exist in an additional two locations. Finally, grain milling is dispersed, with the actual distribution under the confidence bands for short distances, and following overall industry patterns at higher distances. 


\subsubsection{Extending services to towns and rural areas}

21. While economic activities are concentrating in and around the largest metropolis to seek economies of scale and agglomeration, basic services such as water, sanitation, and health care are also concentrated in the same places. ${ }^{15}$ Today, the mandate of providing services to the various urban areas is scattered across several layers of administration (see Box 2) which have been successful in some instances and not so successful in others. Smaller urban settlements and rural areas have limited access to basic services. Figure 10 shows large and sustained rural urban differences in access to piped water and electricity. In 2010, urban access to piped water was estimated at around $22 \%$ in urban areas compared $5 \%$ in rural areas. Similarly, for 2010, urban access to electricity was estimated at $45 \%$ in urban

Figure 10: Large rural urban differences in access to basic and connective services

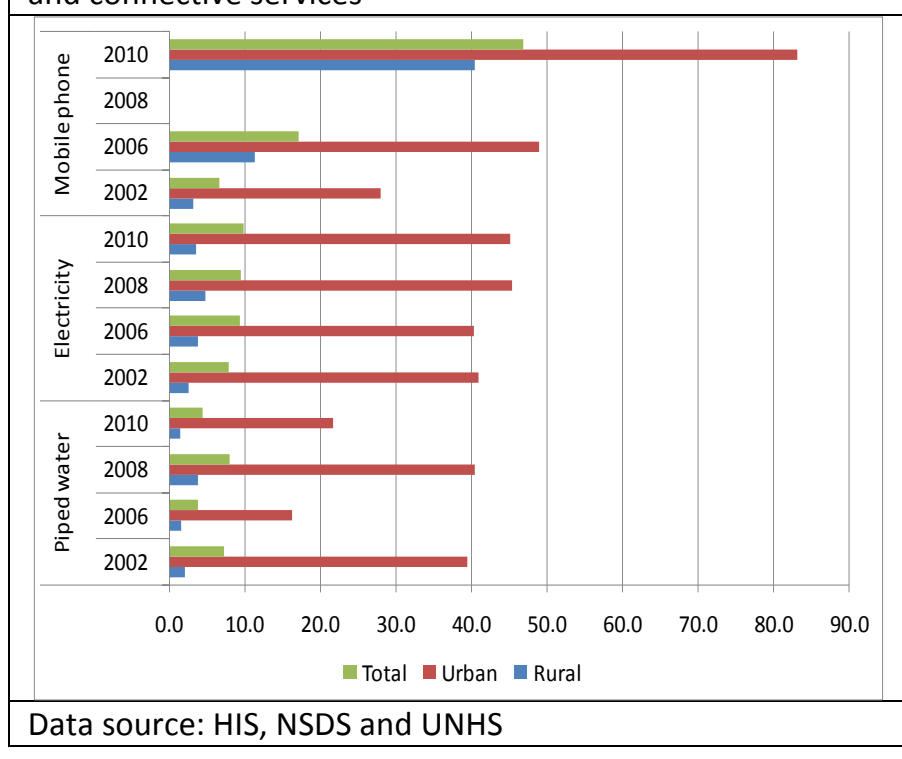
areas, compared to $10 \%$ in rural areas. Among urban areas, electricity access was highest in Kampala at $65 \%$ compared with $32 \%$ in secondary cities, and around $35 \%$ in other urban areas. For piped water, there was very little variation in access across urban areas. Overall, not only are there rural urban differences in access to basic services, differences are quite visible between Kampala and other urban areas for many services (see the statistical annex tables). Identifying whether these differences in access rates are due to affordability or supply constraints needs further examination. And beyond access, improving service quality across urban and rural areas will be important.

Box 2: The Current Institutional Framework for Urban Development

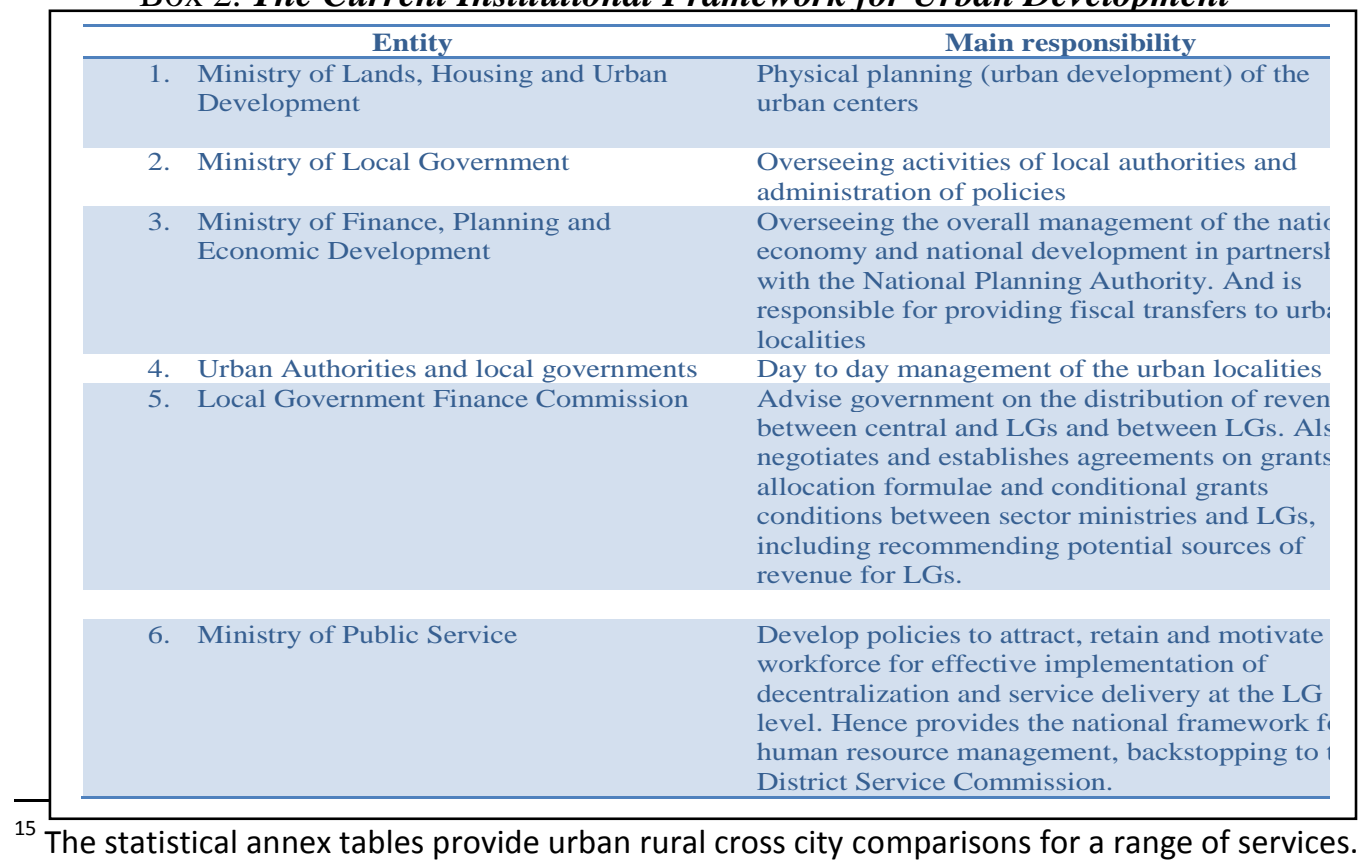


22. In stark contrast, there is spatial equity in primary school enrollments, which are over $85 \%$ overall and there is virtually no difference between rural and urban enrollment rates. While enrollment shares are around the same for private and public primary schooling is urban areas, publicly provided schools dominate in rural areas. Much of the equity in primary school enrollments can be attributed to the governments' UPE program. However, there are quality and cost constraints to actual education outcomes. Dropout rates are higher in rural areas as is proficiency in learning. This, together with unequal access to secondary has led to large differences in secondary school enrollments between rural and urban areas. For the year 2010, secondary enrollment rates were $45 \%$ in urban areas and $19 \%$ in rural areas.

23. In summary, the facts on urbanization and the economy show Kampala dominating the urban landscape, accounting for one-third of Uganda's urban population and connecting the country with the East African economy. However, most of Uganda's population lives in small towns and rural areas, where public policy has not yet been successful in setting up institutional foundations for ensuring universal access to basic services, and reducing impediments for changing land use in anticipation of future market needs. Going forward, it becomes important to amplify the gains from the country's economic engines while planning for urban transformation across the country. The next section identifies specific planning, policy, and investment bottlenecks that limit the pace and returns from urbanization. The focus is on institutional challenges that limit economic density and land use changes, infrastructure that connects rural and urban areas and maintains urban mobility, and targeted interventions for improving living conditions -especially shelter, in cities. Institutions that extend services everywhere are important, but covered in a companion policy note on integrating lagging and leading areas.

\section{Challenges for efficiency and inclusion}

\subsection{Institutions governing land markets}

24. Increasing densities of economic activities is one of the key features of successful urbanization, enabled by reusing the same piece of land for higher value activities over time. Policies that assign property rights and encourage trade of land can enhance economic efficiency and allow settlements to respond to changing needs of the market. Fluid land markets help the transition out of agriculture, where rural land can be sold and/or rented for urban uses, and rural residents can seek more rewarding opportunities in non -farm activities in urban areas. For instance in Vietnam, strengthening of land tenure security quadrupled participation in rental markets from $3.8 \%$ in 1993 to $15.8 \%$ and resulted in an increase in rural urban migration from $29 \%$ in 1993 to $64 \%$ in $1998 .{ }^{16}$ In addition, both rental and sales markets had unambiguously positive impacts on productivity.

25. International evidence identifies positive impacts of tenure security on investment and productivity - however in Uganda, the lack of clear property rights has removed a large proportion of land from the market. In fact, only $18 \%$ of private land is registered and titled. While land registration is not a necessary condition for land tenure security, there is considerable international evidence that it enhances land tenure security by defining the nature and content of land rights, availing all information on land ownership in a public record (the land registry) for inspection and having its correctness assured by the state. ${ }^{17}$

\footnotetext{
${ }^{16}$ Deininger and Jin, 2003

${ }^{17}$ Deininger 2003
} 
26. In addition, unclear property rights and land-related conflicts in Uganda reduce agricultural output by about 8 percent. ${ }^{18}$ Data from the UNHS 2010 show that $37 \%$ of land could not be sold, $34 \%$ could not be rented, and $44 \%$ of land could not be used as security for a loan. This is partly attributed to the predominance of the mailo land tenure system, which is beset by overlapping land rights between those who are registered owners and the lawful or bona fide occupants, as per the Uganda Land Act of 1998. Overlapping property rights on mailo land have created investment disincentives and reduced productivity by up to 25 percent. On the other hand, in western, eastern, and northern regions, customary land tenure systems restricts the sale of land to outsiders to the community.

27. There has also been a decline in land rental markets following the 1998 Land Act and the Land Amendment (2010) Act which has increased powers of tenants over landlords associated with the introduction of the concept of "bona fide" occupants, making it very difficult for landlords to evict tenants. These legal instruments should be reviewed to reverse the unintended effects of dampening the rental land market. Improving fluidity of land markets will require 3 areas of reforms: (i) reducing land conflicts and overlapping land rights on mailo land (ii) reversing a decline in land rental market activity which started in the early 2000s; and (iii) encouraging land rental markets in areas of communal land ownership such as northern Uganda to attract investment there.

28. Reducing Land Conflicts and Overlapping Land Rights. One way to address land disputes is to re-activate the District Land Tribunals which were introduced by the 1998 Land Act but disbanded in early 2000s and take them out of the Judiciary so that they can operate as alternative dispute resolution (ADR) instruments as proposed under the draft National Land Policy. In the case of disputes of specialized nature, the government should strengthen the capacity of local land administration institutions in those particular areas of conflict and accelerate systematic land adjudication and demarcation in those areas; for northern Uganda, communal lands should be demarcated and registered to protect local community land against non-community land incursions. As for overlapping land rights on mailo land, the government should increase funding and improved operations of the Land Fund to extend subsidized loans to bona fide and lawful occupants to buy out residual land rights of landlords.

29. Reversing the Decline in Land Rental Market Activity. The Land Act (1998) and corresponding Land Amendment Act (2010) should be reviewed to reverse the unintended effects of scaring landlords from renting out land. Incentive systems like taxation could also be used to encourage landowners to rent out or sell underutilized or unused land. In this case, the proposed reform of taxing beyond a threshold under the draft National Land Policy should be encouraged.

30. Encouraging land Rental Markets in Areas of Communal Land Ownership. To encourage the flow of capital as well as people with greater agricultural skills into those regions where land sales are discouraged by customary practices, rental markets should be encouraged through demarcation and registration of community lands for many of the clans that are willing to register themselves and own land as Communal Land Associations as provided for under the 1998 Land Act. Such Communal Land Associations will be in a strong position to negotiate with investors seeking long term leases for agriculture.

31. Another important issue in improving fluidity of land markets is to strengthen capacity of land administration institutions. In the medium to longer term, this will help prepare Uganda to set up a system to value land (including an integrated land management/ registration system), manage land transactions (including compensation during acquisition), settle land related disputes, and review regulations that govern land transactions. Even today's highly urbanized countries such as South Korea sowed the institutional foundations for fluidity in land transformation at incipient stages of urbanization (see Box 2).

${ }^{18}$ Deininger and Castagnini (2004) 


\begin{tabular}{|c|c|c|c|}
\hline Incipient & Intermediate & Advanced & Future plans \\
\hline $\begin{array}{l}\text {-Establishing land } \\
\text { management and } \\
\text { ownership } \\
\text { •Adopting building } \\
\text { permits, urban planning } \\
\text { districts, and zoning } \\
\text {-Project bases: Land } \\
\text { Acquisition Act, } \\
\text { Downtown improvement } \\
\text { program(redevelopment), } \\
\text { Land readjustment } \\
\text { program(new } \\
\text { development) } \\
\text {-Agricultural land reform } \\
\text { after Korean } \\
\text { Independence }\end{array}$ & $\begin{array}{l}\text {-Expanding urban planning } \\
\text { districts } \\
\text {-Adopting Floor Area } \\
\text { Ratio regulations('70) } \\
\text {-Land use change permit, } \\
\text { Regulation of } \\
\text { appropriation of } \\
\text { agricultural and forest } \\
\text { lands ('72) } \\
\text {-Project bases: Industrial } \\
\text { base development through } \\
\text { land acquisition by } \\
\text { complete purchase('80) } \\
\text {-Long-term planning } \\
\text { : National land } \\
\text { development plan, urban } \\
\text { comprehensive plan }\end{array}$ & $\begin{array}{l}\text {-Integrating land } \\
\text { use management } \\
\text { systems in urban } \\
\text { and non-urban } \\
\text { areas } \\
\text {-Adopting a } \\
\text { regional } \\
\text { metropolitan } \\
\text { plan system }\end{array}$ & $\begin{array}{l}\text { - Land management } \\
\text { for preventing chaotic } \\
\text { development and } \\
\text { ensuring social equity } \\
\text { - Reasonable, efficient, } \\
\text { and cooperative } \\
\text { planning system } \\
\text {-Urban policies } \\
\text { focused on urban } \\
\text { region }\end{array}$ \\
\hline
\end{tabular}

32. Land market reforms everywhere in the world are encumbered with political economy challenges. Lessons from other countries many times provide some guidance on how to overcome some of these challenges, even though individual country characteristics are critical. Table 2 below provides some hints of where to look in handling the key reforms being suggested in land reforms 
Table 2: Reforming land in spite of political economy challenges

\begin{tabular}{|c|c|c|c|}
\hline $\begin{array}{l}\text { Reforming Land } \\
\text { Markets }\end{array}$ & Political Economy Risks & $\begin{array}{c}\text { Where to learn from } \\
\text { experience? }\end{array}$ & Mitigation Measures \\
\hline \multicolumn{4}{|c|}{ Reform 1. Reduce land insecurity, conflicts and disputes caused by overlapping land rights: } \\
\hline $\begin{array}{l}\text { (i)Activate District } \\
\text { land tribunals as per } \\
1998 \text { Land Act and } \\
\text { Take them out of the } \\
\text { Judiciary back to } \\
\text { Ministry of Lands }\end{array}$ & $\begin{array}{l}\text { There is a stalemate on } \\
\text { whether tribunals should } \\
\text { operate under the umbrella } \\
\text { of Ministry of Lands or the } \\
\text { Judiciary }\end{array}$ & $\begin{array}{l}\text { In Tanzania and Zambia, } \\
\text { the Tribunals are under the } \\
\text { Ministry of Lands }\end{array}$ & $\begin{array}{l}\text { Learn from experience of } \\
\text { other countries and adopt best } \\
\text { international practice }\end{array}$ \\
\hline $\begin{array}{l}\text { (ii) Strengthen } \\
\text { capacity of local } \\
\text { governments in } \\
\text { Bunyoro, Amuru, } \\
\text { etc(ie, the conflict } \\
\text { areas) }\end{array}$ & $\begin{array}{l}\text { Inadequate funding for } \\
\text { decentralization has left } \\
\text { many districts, especially } \\
\text { new ones, grossly } \\
\text { underfunded and weak }\end{array}$ & $\begin{array}{l}\text { Kenya, Tanzania and } \\
\text { Rwanda are stepping up } \\
\text { funding to strengthen } \\
\text { decentralization of land } \\
\text { administration }\end{array}$ & $\begin{array}{l}\text { Publicize awareness of what } \\
\text { other countries are doing to } \\
\text { fund and strengthen } \\
\text { decentralization of land } \\
\text { administration }\end{array}$ \\
\hline $\begin{array}{l}\text { (iii) Effective } \\
\text { management of the } \\
\text { land fund, including } \\
\text { increasing its funding } \\
\text { to give lawful and } \\
\text { bona fide occupants } \\
\text { subsidized loans to } \\
\text { buy out residual } \\
\text { rights of landlords }\end{array}$ & $\begin{array}{l}\text { Well funded Land Fund } \\
\text { could be wrongly perceived } \\
\text { as a political solution to buy } \\
\text { out and silence landlords } \\
\text { regarded as wealthy while } \\
\text { benefiting bona fide and } \\
\text { lawful occupants who are } \\
\text { not regarded as the most } \\
\text { deserving land poor. }\end{array}$ & $\begin{array}{l}\text { Malawi and South Africa } \\
\text { have well designed and } \\
\text { funded land redistribution } \\
\text { programs focused on } \\
\text { poverty reduction; the } \\
\text { Malawi program is funded } \\
\text { by the World Bank }\end{array}$ & $\begin{array}{l}\text { 1. Improve the design, } \\
\text { funding and operations of the } \\
\text { Land Fund to increase its } \\
\text { credibility as a pro-poor } \\
\text { development program } \\
\text { 2. Conduct an awareness } \\
\text { campaign of the } \\
\text { developmental benefits of an } \\
\text { improved Land Fund }\end{array}$ \\
\hline \multicolumn{4}{|c|}{ Reform 2. Promoting land rental market activity: } \\
\hline $\begin{array}{l}\text { (ii) Institute an } \\
\text { incentive system to } \\
\text { encourage rent or sale } \\
\text { of underutilized land } \\
\text { (e.g taxation and or } \\
\text { penalties for hoarding } \\
\text { vacant land for } \\
\text { speculative purposes) }\end{array}$ & $\begin{array}{l}\text { While the draft National } \\
\text { Land Policy advocates for } \\
\text { this policy reform, there is } \\
\text { some opposition among } \\
\text { political leaders who own } \\
\text { lots of land that it would tax } \\
\text { their personal interests }\end{array}$ & $\begin{array}{l}\text { Viet Nam, China and } \\
\text { Thailand have progressive } \\
\text { policies that promote land } \\
\text { rental markets which have } \\
\text { increased land access for } \\
\text { the poor and promoted } \\
\text { transformational growth for } \\
\text { the respective countries } \\
\text { Kenya's new National } \\
\text { Land Policy and new } \\
\text { Constitution provide for } \\
\text { introduction of taxation of } \\
\text { unused land and } \\
\text { prescription of maximum } \\
\text { acreage of private land } \\
\text { ownership }\end{array}$ & $\begin{array}{l}\text { Demonstrate to government } \\
\text { that mutually agreed tenancy } \\
\text { arrangements between } \\
\text { landlords and tenant are } \\
\text { superior to legal threats to } \\
\text { landlords in promoting the } \\
\text { interests of tenants in the way } \\
\text { of increased scope, certainty } \\
\text { and efficiency of land rental } \\
\text { markets } \\
\text { Review and draw from } \\
\text { experiences of other } \\
\text { countries especially Kenya } \\
\text { whose new land policy is a } \\
\text { result of very thorough } \\
\text { professional review and } \\
\text { broad consultations }\end{array}$ \\
\hline \multicolumn{4}{|c|}{ Reform 3. Transforming communal land towards more productivity and benefit for the community: } \\
\hline $\begin{array}{l}\text { Encourage land rental } \\
\text { markets in areas of } \\
\text { communal land } \\
\text { ownership by } \\
\text { promoting the } \\
\text { organization of } \\
\text { communities into } \\
\end{array}$ & $\begin{array}{l}\text { Fear on the part of local } \\
\text { communities where there is } \\
\text { communal land ownership } \\
\text { that the government would } \\
\text { collude with investors to } \\
\text { grab their land under the } \\
\text { guise of providing them }\end{array}$ & $\begin{array}{l}\text { Tanzania, Mozambique } \\
\text { and Ghana have on-going } \\
\text { programs to mobilize } \\
\text { communities into formal } \\
\text { land owning entities and to } \\
\text { survey and register land in } \\
\text { the names of the }\end{array}$ & $\begin{array}{l}\text { Undertake a two pronged } \\
\text { approach to raise awareness } \\
\text { over registration of } \\
\text { community land rights while } \\
\text { also piloting organization of } \\
\text { communal land associations } \\
\text { and registering their land }\end{array}$ \\
\hline
\end{tabular}




\begin{tabular}{|c|c|c|c|}
\hline $\begin{array}{l}\text { Reforming Land } \\
\text { Markets }\end{array}$ & Political Economy Risks & $\begin{array}{l}\text { Where to learn from } \\
\text { experience? }\end{array}$ & Mitigation Measures \\
\hline $\begin{array}{l}\text { communal } \\
\text { associations and } \\
\text { registering their land } \\
\text { rights as per } 1998 \\
\text { Land Act }\end{array}$ & with title deeds & communities & rights \\
\hline \multicolumn{4}{|c|}{ Reform 4. Strengthen capacity of land administration institutions: } \\
\hline $\begin{array}{l}\text { (i) Accelerate the } \\
\text { development of a } \\
\text { land information } \\
\text { system that integrates } \\
\text { land management, } \\
\text { registration and } \\
\text { valuation functions }\end{array}$ & $\begin{array}{l}\text { Manual processes and poor } \\
\text { systems of land records } \\
\text { contribute to inefficiency } \\
\text { and lack of transparency in } \\
\text { land administration }\end{array}$ & $\begin{array}{l}\text { Many countries world-wide } \\
\text { and in the region including } \\
\text { Rwanda, Kenya and } \\
\text { Tanzania are re- } \\
\text { engineering and } \\
\text { computerizing processes, } \\
\text { workflows and land } \\
\text { records to improve } \\
\text { efficiency and transparency }\end{array}$ & $\begin{array}{l}\text { Disseminate and publicize } \\
\text { international good practices } \\
\text { to gain political support for } \\
\text { on-going computerization } \\
\text { initiatives }\end{array}$ \\
\hline $\begin{array}{l}\text { (ii) Accelerate the } \\
\text { registration of land } \\
\text { rights }\end{array}$ & $\begin{array}{l}\text { In some parts of the country, } \\
\text { there is misplaced suspicion } \\
\text { by local communities that } \\
\text { systematic land titling } \\
\text { programs could lead to a } \\
\text { loss of their land by wealthy } \\
\text { and politically connected } \\
\text { people }\end{array}$ & $\begin{array}{l}\text { Kenya has more than } 35 \\
\text { percent of its land already } \\
\text { registered compared to } 18 \\
\text { percent for Uganda; } \\
\text { Rwanda will have all its } \\
\text { land registered by the end } \\
\text { of } 2013 \text { and Tanzania is } \\
\text { planning a big program of } \\
\text { systematic titling after it } \\
\text { registered success in } \\
\text { piloting it }\end{array}$ & $\begin{array}{l}\text { Increase awareness of results } \\
\text { from piloting systematic land } \\
\text { titling in order to gain } \\
\text { support for scaling it up }\end{array}$ \\
\hline $\begin{array}{l}\text { (iii) Clarify and } \\
\text { strengthen the } \\
\text { respective roles of } \\
\text { local and central } \\
\text { agencies in land } \\
\text { administration }\end{array}$ & $\begin{array}{l}\text { Land administration is weak } \\
\text { at local level in part because } \\
\text { of poor funding and lack of } \\
\text { anticipation that many more } \\
\text { new districts would be } \\
\text { created after the Land Law } \\
\text { was passed in } 1998\end{array}$ & $\begin{array}{l}\text { Tanzania, Kenya and } \\
\text { Rwanda are re-examining } \\
\text { their decentralization } \\
\text { arrangements for land } \\
\text { administration with a view } \\
\text { to matching the } \\
\text { decentralized functions } \\
\text { with resources available to } \\
\text { execute them at local level }\end{array}$ & $\begin{array}{l}\text { Review and draw from } \\
\text { experiences of other } \\
\text { countries to refocus } \\
\text { decentralization of land } \\
\text { administration so that it can } \\
\text { become effective and } \\
\text { sustainable }\end{array}$ \\
\hline
\end{tabular}

\subsection{Planning to manage urban change}

33. The growth of Ugandan cities has been unplanned - with high rates of spatial expansion (sprawl) and unplanned growth, lack of integration between sectoral and spatial planning, inadequate provision of basic services, weak urban management capacity and significant fiscal constraints. As a consequence, congestion diseconomies are setting in early and limiting the ability of towns and cities to exploit agglomeration economies. Chaos prevails with the landscape dominated by informal housing and slums and a deteriorating urban environment. Currently about $60 \%$ of urban population live in unplanned settlement (slums) and dirt roads make up a large percentage of the road network with the few tarmac ones full of pot holes. There are no street lights, drainage channels are inadequate and silted, scattered waste (both organic and inorganic) contaminates water sources when they overflow during the rainy season; and water and sanitation services are lousy with majority of the population not connected to neither piped water nor sewer. 
34. Urban health has been compromised by the nature of urban development that exposes a majority of urban dwellers to disease outbreaks - primarily due to inadequate infrastructure and sanitation facilities in the informal settlements. Drainage channels are also open sewers that run through neighborhoods. For example in Kampala City, cholera outbreaks have occurred frequently since 1997 with the most recent between October 30th and mid January 2007 that registered 634 cases with 9 deaths.

35. Urban water supply is the responsibility of the National Water and Sewerage Corporation $(N W S C)^{19}$. Although Uganda is endowed with a number of fresh water bodies ${ }^{20}$ which covers about $18 \%$ of its surface area, there are great disparities in availability and use within the country because water resources are unevenly distributed. Currently the NWSC is responsible for provision of water and sanitation in nineteen urban centers. ${ }^{21}$ It supplies about 1.4 million customers with 150 million liters per day. Water in small urban centers (towns) is the responsibility of the Directorate of Water Development (DWD) which provides grants to small towns to extend piped water to individual households. However, sometimes access and the amount needed are compromised due to the problem of affordability of the water tariff. As a result people resort to other sources such as springs, wells and boreholes, which sometimes are contaminated. Table 2 shows the urban access to water by source which indicates that over $30 \%$ of urban dwellers $(55 \%)$ is without access to suitable water services.

Table 3 - Urban access to water by source

\begin{tabular}{|c|c|c|c|c|c|c|}
\hline & 2002 & 2006 & 2010 & 2002 & 2006 & 2010 \\
\hline & \multicolumn{3}{|c|}{ Population } & \multicolumn{3}{|c|}{ Household } \\
\hline Tap/Piped Water & 53.6 & 54.5 & 64.3 & 57.1 & 56.4 & 67.0 \\
\hline Bore-hole & 15.0 & 14.3 & 13.9 & 13.4 & 12.1 & 11.6 \\
\hline Protected Well/Spring & 18.9 & 18.8 & 14.0 & 16.5 & 17.5 & 12.8 \\
\hline Other & 12.5 & 12.5 & 7.8 & 13.0 & 14.0 & 8.7 \\
\hline Total & 100.0 & 100.0 & 100.0 & 100.0 & 100.0 & 100.0 \\
\hline
\end{tabular}

Data source: UNHS

36. Basic hygiene practices including safe water and proper sanitation are also lacking in many urban communities. Piped water and sewerage services combined are available for only about $8 \%$ of urban dwellers while the rest of the urban population predominately use either pit latrines or septic tanks and household level. The situation is getting worse with rapid population growth increased with unplanned spatial expansion of urban areas.

37. Solid waste disposal - Under the LG Act CAP 243, solid waste collection, transportation and disposal is one of the responsibilities of local governments. In most urban areas the standards of refuse disposal is generally low. Table 3 below summarizes the methods of solid waste disposal in urban areas. The most serious problem of solid waste management in urban LGs is associated with the lack of treatment and disposal facilities. The unscientific manner of disposal of solid waste, dumping in open sites and low lying areas constitutes a serious public health issue.

\footnotetext{
${ }^{19}$ The NWSC is a public Corporation wholly owned by the GoU established under the NWSC Act to operate and provide water and sewerages services in areas entrusted to it under the Water Act.

${ }^{20}$ Lakes, rivers, springs, wells

${ }^{21}$ Kampala (including Kajjansi and Nansana), Jinja/Njeru, Entebbe, Tororo, Mbale, Mbarara, Gulu, Lira, Fort Portal, Kasese, Kabale, Arua, Bushenyi/Ishaka, Soroti, Mukono, Malaba, Iganga, and Lugazi towns.
} 
Table 3 - Methods of disposal of solid waste in urban areas

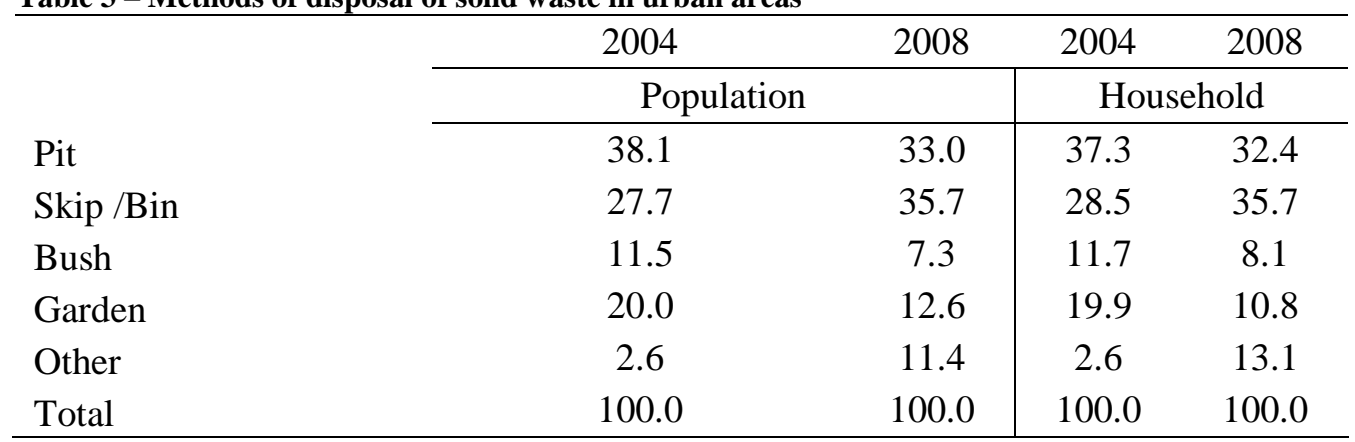

Data source: NSDS, UBOS, 2005 and 2009

38. Drainage-Most urban centers have poor drainage networks. The few which are there are not well maintained. This problem is further compounded by people indiscriminately dumping garbage in the drains causing silting and flooding. The problem of poor drainage has made it difficult to construct pit latrines. The few which have been constructed are made shallow, resulting into quick filling and low incomes have generated limited demand for cesspool services. In most cases such filled-up pit latrines are opened to flow into the open drains. Coupled with indiscriminate dumping of garbage the drainage systems in most urban areas, including Kampala City, is silted and blocked.

39. Planning for 'orderly' urban development infrastructure and has become particularly challenging as the 1995 constitution created private land ownership and abolished land leases vested with urban local bodies. Fragmentation of land parcels and rapid suburbanization has ensued, with fiscally starved local governments unable to acquire land and protect rights of way for infrastructure improvements.

40. Part of the urban chaos is due to the absence of a national urban policy and a weak legal framework. Uganda does not have an urban policy to guide the urban despite the importance of the sector to the economy. It would be important Government to formulate an appropriate urban policy and empower urban councils to implement and enforce the provisions of the recent Physical Planning Act, 2010. To operationalize this act, the department of Physical Planning in urban LGs need to strengthened and equipped; and the managers of urban LGs need to be empowered to enforce plans. Orderly urban development is a product of proper planning and management of urban land. In Uganda urban managers are constrained by the existing national legal framework that allows private individuals to hold land in perpetuity. There is therefore need to harmonize land laws to enable urban managers influence land use including making them become the area land committee of the respective urban region as opposed to the current practice where urban land is under District land committee.

41. While planning for future urban expansion and development is key, planners and policymakers should resist the temptation of developing master plans. It may be better to produce a much simpler spatial strategy document that could be updated every year by staff of a city's urban planning department. The emphasis of such a document would be on the current spatial situation and spatial trends. It main objectives would be on ensuring housing and land affordability and adequate mobility. Such a process would focus on analyzing real estate prices and supply and demand constraints for all income groups, firms and households. The plan would cover three topics: (i) land use and spatially distributed demographics; (ii) road and transport networks; and (iii) land use and development regulations. Rather than attempting to cover all sectors, when the spatial strategy is approved by government, it could be distributed to line agencies that have the technical expertise to develop plans consistent with their program budget constraints, investments that are consistent with the spatial distribution of the population. It is important to provide the line agencies with a constantly updated spatial distribution of populations so that they can adjust to their investment programs to meet current and future demand. 
42. This is not a revolutionary proposal. Most master plans around the world are largely ignored (even in China). In Vietnam these plans are often referred to as "Hanging Plans" suggesting that they often decorate the walls of planning departments, but are rarely implemented. Changing the planning process to be more in line with market dynamics would lead to better and consistent development outcomes. Singapore and Hong Kong are good examples of land use planning and internal consistency between spatial objectives and the provision of physical and social infrastructure.

\subsection{Connectivity and mobility within cities}

43. Spatially integrated labor markets enhance the economic efficiency of cities. The spatial extent of urban areas and efficiency of the urban economy is reduced with diseconomies from congestion. However cities in Uganda, as in most of East Africa are mobility constrained. There are concerns that motor vehicle ownership is on the rise, with cars and station wagons increasing from 11,000 in 2002 to over 27,000 in 2009, and motorcycles increasing almost tenfold from 11,000 to over 100,000. ${ }^{22}$ While the pace of motorization may appear alarming, these trends are only going to accelerate as incomes rise and cost of vehicles reduce. The challenge here is to manage private vehicle use, rather than focus on vehicle ownership.

44. In the absence of strategic planning to accommodate long term growth, cities will face challenges in coordinating, acquiring, planning and developing land for infrastructure (or for "public use" in general). Weak fiscal capacities of local governments exacerbate the problems of compensating landowners at market rates. Own source revenues are derived from trading licenses, cultural heritage, property rates, occupation permits, administrative fees like parking fees, livestock and abattoir fees, and market dues. Urban Local Governments also receive revenues through professional levis, fines and penalties, graduated tax compensation from central government, statutory transfers from central governments (unconditional grants, conditional grants, and equalization grants), fee for approval of building plans, local service tax, ground rent and premium, rental of urban council facilities (halls, buildings and compounds) for private functions. With the exception of Kampala City which raises about $50 \%$ of its budget from own source revenue, all other urban councils in Uganda depend on central government transfers to finance development programs. ${ }^{23}$

45. Since provision and financing of urban roads are responsibilities of urban local governments - their limited finances do not allow them to finance compensation for land acquisition as well as maintaining existing road networks. As a consequence, the main arteries in urban areas - particularly in Kampala - are getting rapidly congested. The congestion challenge is compounded by the Government's decision to divest itself from provision of public transport. Public transport in Uganda now is dominated by 14 seater private mini buses and there has been an explosion of private motor vehicles (estimated to be growing at $11 \%$ per year). Traffic snarls are a big problem particularly in Kampala, which receives 1 million people commuters into the city. Transport experts suggest that the public transport system in Kampala could be improved by (i) signalization at major junctions and conversion of some streets to one way (traffic management), and (ii) widening of some streets and making provision for a bus rapid transit (BRT) system (capacity expansion).

\footnotetext{
${ }^{22}$ Data source: Uganda Revenue Authority

${ }^{23}$ Martin (2011). Background paper
} 


\subsubsection{Box 3: Integrating land use and transport planning -smart growth and transit oriented development}

Smart growth generally calls for higher-density settlement with an emphasis on providing a balanced mix of housing, jobs, and shopping opportunities within a community. The origin of this trend is often attributed to the experience of the Brazilian city of Curitiba, which outlined Master Plan in 1965, with the main goals of limiting central area growth and encouraging commercial and service sector growth along two structural north-south transport arteries, radiating out from the city center.

Two co-ordinated planning instruments were combined in implementationof the plan.

Development control was used pro-actively. On land sites located along the structural axes local legislation permits buildings to have a total floor space up to six times the total plot size. Developments close to other roads with good public transport are allowed floor space up to four times plot size. The coefficient decreases the further a site is from public transport. This encouraged new commercial developments outside the city,along each structural axis, and also high density residential developments so there is a match between residential and commercial areas and public transport provision.

Second, planning for public transport was incorporated centrally in land-use planning. The city center was pedestrianized with access to public transport but not to private transport. Each of the five main arteries contains one two-way lane devoted exclusively to express buses. This inner lane is flanked on either side by 1) a local access lane for cars and 2) a high-capacity one-way route for use by both cars and buses. Separating traffic types and establishing exclusive bus lanes on the city's predominant arteries helped to ensure a safe, reliable, and efficient bus service operating without the hazards and delays inherent to mixedtraffic bus service

As the problems of motorization have become more apparent, many cities in the world have begun to think further in terms of "transit oriented development" (TOD), the major element of which is a congregation of housing, jobs, shops, and other activities around mass transit stations. Associated with improved access to these varied land uses, the physical environment is often enhanced with wide sidewalks, an absence of surface parking lots and large building setbacks. TOD is not only relevant to new development where a high capacity public transport system has been created. For example, TOD around the BRT network in Brisbane, Australia, can be classified in three categories. First, the busways are serving existing areas that had many TOD characteristics, but lacked a dedicated transit connection. Second, the busways are serving as a catalyst for new, green field development near stations. Finally, the busways are catalyzing urban infill, including significant air rights development.

46. The main challenge confronting rapidly growing and expanding cities is to maintain labor mobility while ensuring that land and property prices remain affordable to a majority of households. Land use and mobility are closely interconnected in principle - but difficult to coordinate in practice. Maintaining urban mobility requires investments in trunk infrastructure and assigning rights of way - which have to be planned and financed in advance, where as the supply elasticity of housing depends to a larger extent on idiosyncratic preferences of where households want to live (depends on tastes, incomes, etc). Innovations such as smart growth and transit oriented development are bein tried out in some countries to integrate land use and transport - these need to be examined to see how these can be tailored to Uganda, keeping in mind that incomes and institutional capacities for implementation and execution will improve over time (see Box 3 for examples of these innovations). 
47. However, public transport is unaffordable to many at current income levels. Data reported in the UNHS suggest that $64 \%$ of urban dwellers walk to work, and walking trips are as high as $70 \%$ in Kampala (figure 12). As cities in Uganda are expanding their spatial footprints, the limited reach of walking trips severely limits labor market opportunities for people who live further away from economic centers, and may even exacerbate slum formation as many people will tradeoff housing quality to be close to jobs. Typically, transport choice is determined by incomes, with the mode and number of trips increasing with incomes. What little data available shows that households in Kampala pay US\$ 13 per month on transport fares, which is about 8 percent of the household budget. While this is consistent with global estimates of what people pay for transport, transport fares are particularly high for the poor. In fact, the $20 \%$ of households end up paying $41 \%$ of their incomes on transport - which makes transport services unaffordable to this group. This is consistent with the situation in many African cities. ${ }^{24}$

\begin{tabular}{|l|l|l|}
\hline Figure 12: How people get to work? & \multicolumn{2}{|c|}{ Kampala } \\
\hline All urban areas & \\
\hline \multicolumn{2}{|c|}{ Motorcycle, 0 Bicycle, 0} \\
Other, 2.6
\end{tabular}

48. In Addis Ababa, 70 percent of trips are by walking and public transport is estimated to cost 3-37 percent of household income, with average distance walked is $5 \mathrm{kms}$. In Nairobi, it is $4 \mathrm{kms}$, where 48 percent of trips are by nonmotorized transport, including walking - and the poor pay 34 percent of their incomes on transport. And in Dar es Salaam, the average distance walked is $2.2 \mathrm{kms}$ and share of non motorized transport is 45 percent, with transport expenditures for the poor accounting for 53\% of incomes. ${ }^{25}$ This implies that at low income levels, the wider availability of different service levels and modes at different prices is a useful strategy for provision of urban transport services.

${ }^{24}$ AICD, stuck in traffic.
${ }^{25}$ SSATP 2002 and AICD 
49. While most people walk, there are hardly any facilities and safety standards to protect pedestrian road users (figure 13). Improving sidewalks and street lights and other measures to protect pedestrian users should be important in an urban transport strategy. The wide availability of choices is an essential feature of a responsive strategy. In the short term, it is important to enable the availability of a wide range of service levels / modes at different prices - and invest in sidewalks to reduce pedestrian fatalities in traffic accidents. In the longer term, policies for taxing motor vehicle use (say with gasoline taxes) and supply of public transport choices will be Figure 13: Pedestrian fatalities highest in road accidents

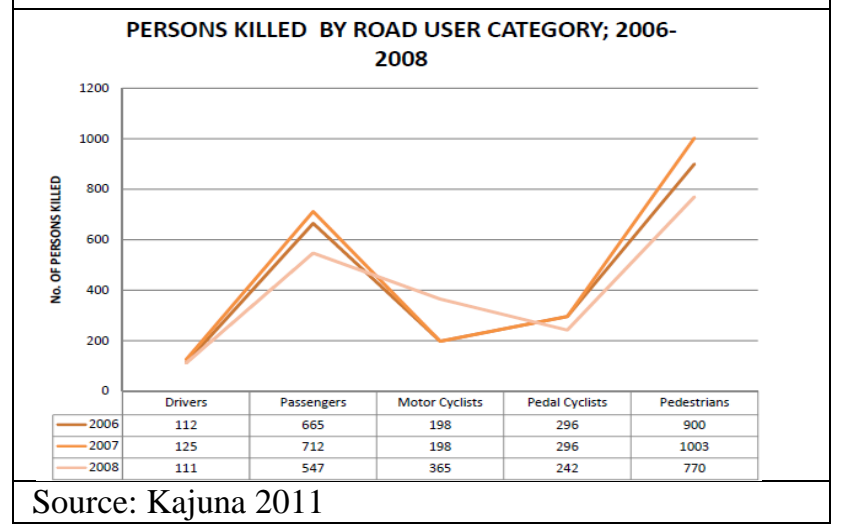
necessary components of a functioning urban area.

\subsection{Connectivity across cities}

50. As economic activities concentrate along the corridors linking Kampala and Eastern Africa, it becomes important to improve connectivity of the metropolis with neighboring urban and rural areas. To help prioritize transport investments, an econometric and simulation exercise was carried out to rank order locations where transport improvements would generate the highest returns. As discussed earlier in this note. ${ }^{26}$ Uganda's industry is clustered and dominated by production activities that are standardized and require low technology by global standards. These include food processing, garments and textiles, clay products and furniture. However, many of these products and business lines are new to the country, so they can be considered locally as "sunrise" activities, while being "sunset" activities globally. The econometric model of location choice examined the factors influencing the decisions of entrepreneurs to locate industrial establishments (as reported in the business registry). The choice set includes all 56 districts (using 2002 definitions) in the country. The model has a good predictive fit and successfully predicts actual location decisions for 98 percent of the firms in the sample. The main drivers of industry location are the following:

- Market access, measured by transport connectivity to cities of 100,000 or more people

- Access to the power grid

- Urbanization economies (economic diversity)

- Human capital (availability of workers who have primary or more schooling)

51. Based on the location analysis, areas were identified where public infrastructure investments will produce the highest economic returns in terms of national industrial growth. If we consider the location attributes of districts to be fixed in the short term, the effects of infrastructure improvements will depend on the relative 'stock' of these attributes across districts. Based on the model, the relative profitability to manufacturing firms across districts is predicted (see figure 14). From this figure it is clear that expected profits are highest in Kampala, Wakiso and Jinja. These are high return areas for private manufacturing. Districts at the borders of these agglomerations and those along the road leading to the Kenyan border also offer profitable opportunities for manufacturing

\footnotetext{
${ }^{26}$ See Lall et al (2009) for details
} 


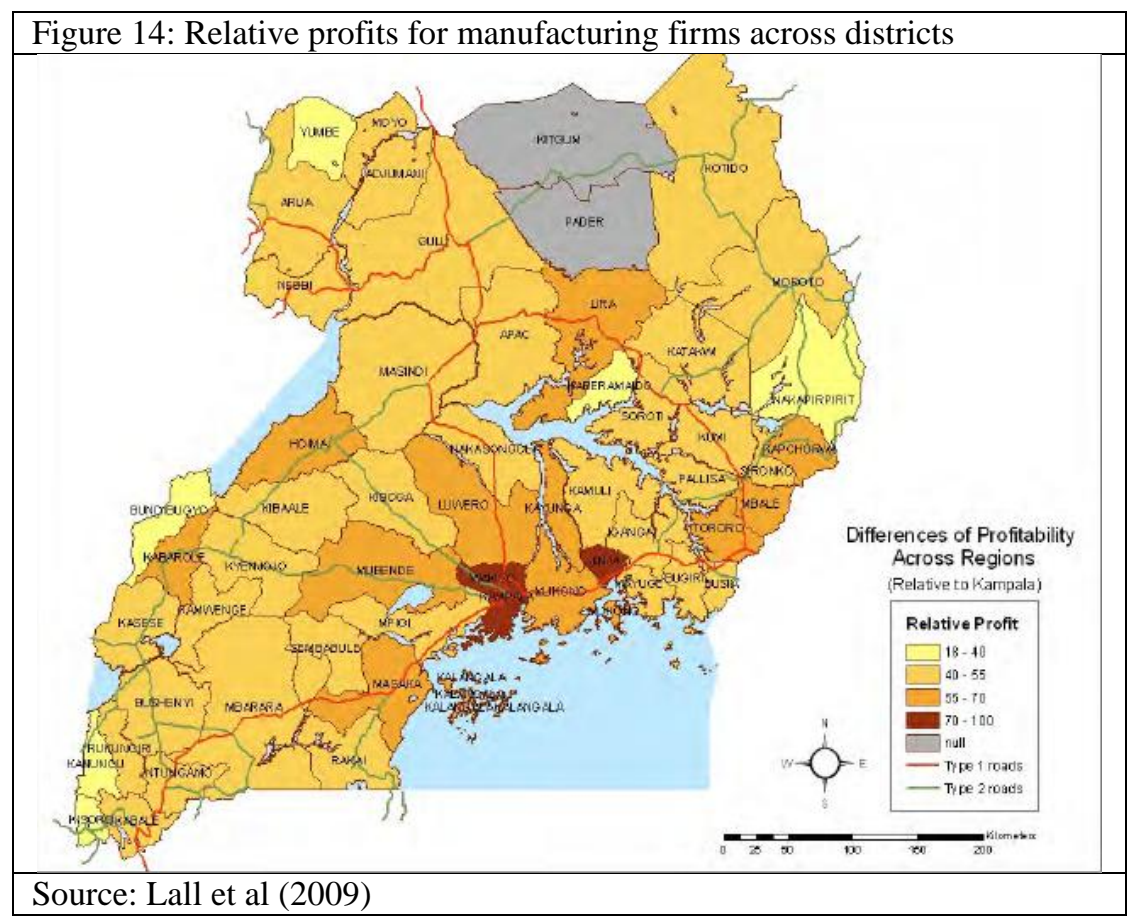

52. Given the distribution of relative profits and the 'preconditions' for success, it is possible to simulate where infrastructure investments will produce the highest returns? Two scenarios are considered:

- In the first case, road conditions are simulated to improve around the Northern cities of Gulu and Lira to increase travel speeds from 60 to $100 \mathrm{~km} / \mathrm{h}$. This would reduce the time it takes to travel from these cities to market centers of 100,000 people from an average of 5 hours to 3 hours.

- In the second case, roads conditions are simulated to improve around high profit cities- Iganga, Mpigi and Mubende, which are in the country's main industrial agglomeration. Again these road improvements are assumed to increase travel speeds from 60 to $100 \mathrm{~km} / \mathrm{h}$.

53. In the simulation, improving roads has two effects. First, it could increase access to markets, and second it would increase the spatial extent of agglomeration economies as firms can effectively be 'closer' to a larger number of firms in their industry. The simulations show that transport improvements only provide modest gains for industry location in the Northern districts of Gulu and Lira. In Gulu, the share of national food and beverage establishments increases from 1.7 percent to 2 percent. In Lira, it moves from 1.9 to $2.3 \%$. In comparison, in Iganga district that adjoins Kampala, transport improvements increase the share of establishments that would locate in the district from 5.8 percent to 10.5 percent.

54. Overall the "pull" of agglomeration economies is strong and reduces the impact of complementary investments to decentralize manufacturing activity. This simple simulation exercise uses results from the empirical analysis and identifies that private returns to public infrastructure investments, measured by new industrial development, is highest in areas that offer "preconditions" for success. In particular, the stock of human capital and an existing mix of diverse economic activities are important ingredients in a successful growth "recipe". And these hese preconditions are offered in the country's main urban agglomerations. 
55. In addition to the econometric evidence that supports connectivity improvements around Kampala and neighboring districts, recent evidence points out that the cost of interaction is considerably higher along the Kampala - Mombasa corridor relative to Southern Africa as well as in countries such as China, Brazil and the United States. Transport prices are US 8 cents per km between Mombasa and Kampala, compared with US 6 cents between Durban and Lusaka, US 5 cents in China and 4 cents in the United States (figure 15). What are the priorities for reducing transport prices?

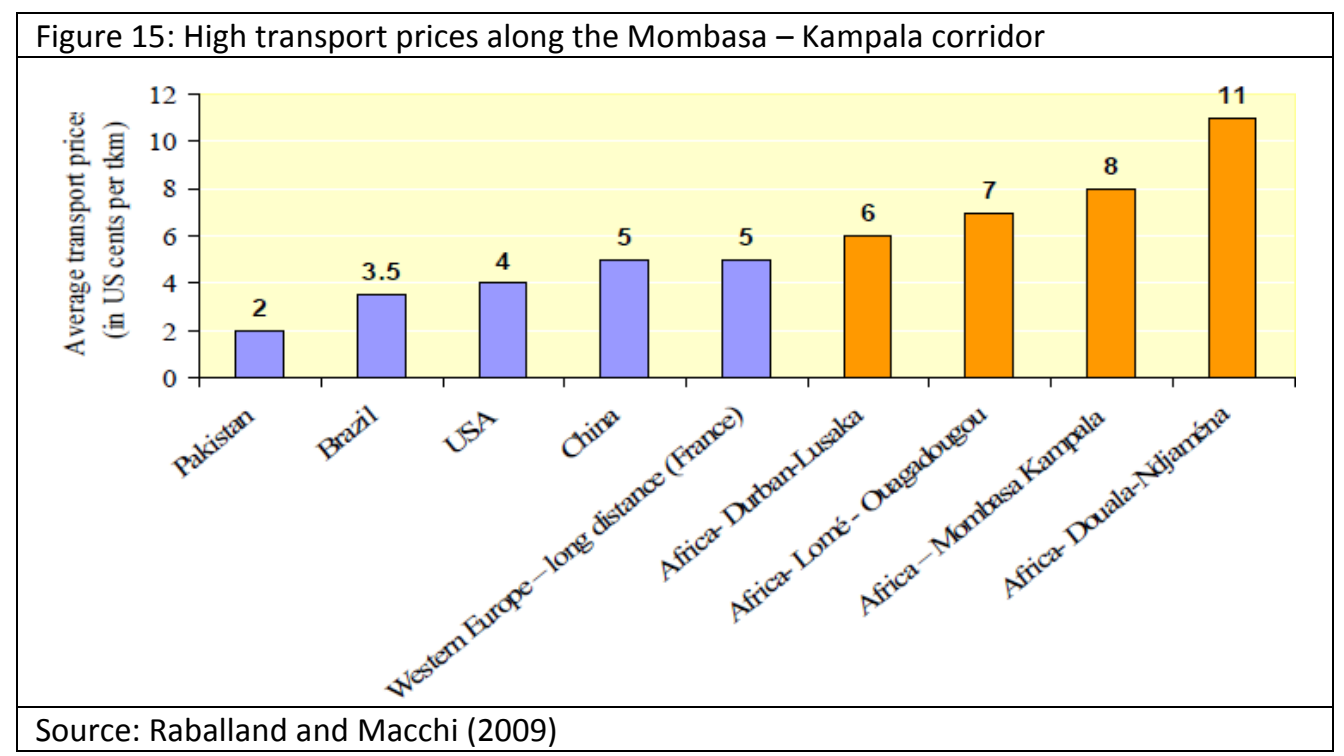

1. Realize that there is a substantial disconnect between transport costs and prices, indicating a strong sellers market. Transport costs between Mombasa and Kampala are about USD 1.33 per vehicle -km, comparable to Western Europe with USD 1.5 per vehicle km in France and Spain and USD 1.7 per vehicle km in Germany. While variable costs are higher in Africa because of: (i) high costs of fuel; (ii) old age of truck fleets, which lead to a higher fuel consumption; and (iii) probably worse roads condition; these are offset by lower fixed costs due to wages and lower capital cost associated with the use of aged truck fleets.

2. Despite poor efficiency factors (low yearly vehicle utilization rates, aging vehicle fleet, unbalanced trade, etc.), trucking companies can still charge high price, and have relatively large profit margin along some corridors. In fact, profit margins along Mombasa Kampala corridor are $86 \%$, much higher than in Southern Africa where profits are around $18 \%$.

3. Poor road conditions may not be the most critical factor for high transport costs - market regulation are likely to matter more. In fact, truckers have reported that $86 \%$ of the corridor between Mombasa and Kamapla, and 75\% between Kampala and Kigali is in good condition.

56. When considering the importance of extra -urban connectivity, policy priorities for Uganda would include addressing the regulatory institutions that may be limiting competition in the trucking industry (and leading to cartel pricing), improving the internal efficiency of the transport industry (increase fleet utilization), and strategically improving infrastructure quality in select segments. The main caveat is not to get carried away with infrastructure improvements without addressing regulatory impediments. Box 4 provides examples of freight transport regulatory reforms in OECD countries. 


\subsubsection{Box 4 Regulatory reforms in road freight: case studies in OECD, Mexico, and South Korea}

OECD countries (Boylaud and Nicoletti, 2001)

The road freight industry has grown very rapidly. There has been a tendency in many OECD countries to implement major liberalization reforms. Two broad categories of road freight regulations exist: (i) regulations on traffic and vehicles, and (ii) regulations on the operations of the market. The challenge facing road freight regulators is to do so without limiting intra-industry competition and competition with other modes of freight transportation.

The available empirical evidence suggests that liberalization has promoted efficiency and consumer welfare. None of the adverse consequences feared by the industry have come about: in reforming countries competition is thriving in a stable industry environment and safety levels have generally improved. At the same time, freight rates have been reduced, productivity has been enhanced and innovative activity stimulated. In the future, viable comparative measures (indicators) of economic performance in the road freight industry should be identified.

Mexico (Dutz et al., 2000)

From an extreme degree of rigid regulation and government interference, Mexico implemented from 1989 regulatory reforms for the road transport industry based on free entry and market- based price setting. Main lessons of Mexico's experience for other countries include: (1) The positive role of increased competition in the road freight industry in fostering economy-wide innovation and growth; (2) Successful reform requires careful planning, execution and high-level political support; (3) Sufficient attention and resources should be devoted to assist the oversight institution in adapting to post-regulatory reform conditions; (4) Pro-market rules to offset remaining market failures should be introduced concurrently with removal of distortionary anti-competition rules; and (5) The competition agency has a critical role to play in any regulatory reform initiative, both in terms of upfront advocacy and ex post enforcement activities.

However, there are still unresolved issues that hold back a full-scale logistics revolution in Mexico: (1) The persistent segmentation between large, technologically sophisticated providers of road freight services and lowtechnology fringe providers; (2) The Mexican government's unwillingness to enforce technical standards and maximum load restrictions, and (3) Failure to fully implement the transportation related provisions of NAFTA and to ensure more homogeneous federal-state regulatory reforms.

South Korea (Smith et al, 1986)

When South Korea reached the intermediate stage of urbanization in 1984, the Korean Government evaluated the regulations governing its trucking industry. Its objective was to find whether deregulation could bring down costs, contribute to energy conservation, and serve users better. The study, overseen by the World Bank, drew the conclusion that the benefits of regulatory reform in trucking would indeed be large: US\$ 240-400 million per year (about 6-9\% of total trucking expenditure).

\subsection{Targeted interventions to improve slums and housing}

57. Rapid population growth and rural urban migration has generated housing shortages in many urban areas. The private sector, which generates most of the housing units has only been able to meet a small share of demand, and the Government owned developer - the National Housing and Construction Company (NHCC) has built only 2300 housing units in the last 30 years - about 77 units only on average per year. The Uganda Population and Housing Census of 2002 and the National Household Survey $2002 / 03$ estimate a backlog of 83,000 houses in Kampala alone. And reports suggest that $85 \%$ of the 
city's population lives in slums - higher than most East African countries. ${ }^{27}$ Nationally there is a housing shortage of 560,000 units, with over 400,000 in rural areas (Table 4). The housing challenge is exacerbated by the complex land tenure system where the Constitution vested land ownership to residents with urban authorities no longer holding statutory leases. ${ }^{28}$

Table 4-Housing Shortages in Uganda

\begin{tabular}{|l|l|r|r|r|r|}
\hline No & Indicator & \multicolumn{1}{l|}{ Kampala } & \multicolumn{1}{l|}{ Urban } & \multicolumn{1}{l|}{ Rural } & \multicolumn{1}{l|}{ National } \\
\hline 1 & Population ('000,000) & 1.359 & 3.829 & 23.523 & 27.352 \\
\hline 2 & Average Household size(Person/household) & 3.800 & 4.100 & 5.300 & 5.091 \\
\hline 3 & Estimated housing need ('000,000) & 0.358 & 0.934 & 4.438 & 5.372 \\
\hline 4 & Estimated housing stock ('000,000) & 0.275 & 0.778 & 4.035 & 4.813 \\
\hline $\mathbf{5}$ & Housing backlog/Deficit ('000,000) & $\mathbf{0 . 0 8 3}$ & $\mathbf{0 . 1 5 6}$ & $\mathbf{0 . 4 0 3}$ & $\mathbf{0 . 5 5 9}$ \\
\hline
\end{tabular}

Source: The 2002 Uganda Population \& Housing and Uganda national Household Survey 2002/03.

58. It is projected that by 2035 Uganda's population will be 68 million of which $30 \%$ ( 20 million) will be in the urban areas. At an average household size of 4 persons, this would mean the total number of housing stock required for the urban sector would be 5 million units of which about 1.02 million would be required for Kampala City alone. At the current level of stock this means additional 4 million units have to be build between now and 2035 (about 134,000 units per year).

59. How can the daunting housing shortages be reduced? And what types of targeted interventions are needed? The following insights can help:

- Income levels and household characteristics are the main determinants of housing demand. The income elasticity of housing is less than unity - this implies that at low income levels households spend a substantial portion of their incomes of housing, leaving very little discretionary income for other expenditures. Housing demand changes with changes in incomes and movements along the life cycle. People with low and uncertain incomes find it difficult to enter the owner occupied housing market and prefer to be renters. This provides them with greater flexibility in choice for future mobility. Yet most government sponsored housing programs for the poor tend to promote ownership housing. It was only in the 1980s that the rental council housing

Table 5: Rental housing : Share with non-zero expenditures on rent

\begin{tabular}{|lcccccc|}
\hline \multirow{3}{*}{ Cities } & \multicolumn{7}{c|}{ National welfare quintile } & \multirow{2}{*}{ Total } \\
\cline { 2 - 6 } Kampala & Q1 & Q2 & Q3 & Q4 & Q5 & \\
\cline { 2 - 6 } Masaka & 100.0 & 79.8 & 76.1 & 65.9 & 68.6 & 69.1 \\
Jinja & 0.0 & 31.6 & 42.9 & 62.3 & 39.3 & 47.2 \\
Mbale & - & 70.1 & 71.8 & 69.8 & 69.6 & 70.0 \\
Arua & 0.0 & - & 100.0 & 100.0 & 46.1 & 56.8 \\
Gulu & 100.0 & 100.0 & 0.0 & 50.0 & 58.9 & 57.1 \\
Lira & - & 50.0 & 0.0 & 20.6 & 42.3 & 32.7 \\
Mbarara & 0.0 & 26.1 & 0.0 & 93.3 & 71.7 & 65.8 \\
Other Urban & - & - & 73.0 & - & 79.9 & 79.1 \\
\hline Data source: UNHS 2010 & 52.1 & 25.9 & 48.0 & 56.3 & 48.2 \\
\hline
\end{tabular}
in the UK was converted to owner occupied housing. As needs change, households would like to change their housing consumption bundle accordingly. Using data from the UNHS it is evident that significant shares of urban households pay rent for their homes - and the poor are more likely to be renting than the better off (table 5, using national income distribution). A similar pattern in evident

\footnotetext{
${ }^{27}$ Source:: LSE paper

${ }^{28}$ The Constitution provides for the following four land tenure systems - Mailo land tenure, Freehold land tenure, Customary land tenure, and leasehold land tenure systems.
} 
when one zooms into Kampala - where $78 \%$ of the poorest quintile rent their homes, compared with $63 \%$ for the richest quintile (table 6). Demand for home ownership will increase with incomes, but a range of shelter and tenure options need to be available to urban residents.

\begin{tabular}{|c|c|c|c|c|c|c|c|}
\hline Poverty status & Owned & $\begin{array}{l}\text { Rented } \\
\text { (Normal) }\end{array}$ & $\begin{array}{c}\text { Rented } \\
\text { (subsidized) }\end{array}$ & $\begin{array}{l}\text { Supplied free } \\
\text { by employer }\end{array}$ & $\begin{array}{c}\text { Supplied free or } \\
\text { rent paid by } \\
\text { relative }\end{array}$ & Other & Total \\
\hline Non-poor & 22.2 & 67.9 & 1.6 & 3.4 & 4.4 & 0.6 & 100.0 \\
\hline Poor & 15.5 & 84.5 & 0.0 & 0.0 & 0.0 & 0.0 & 100.0 \\
\hline \multicolumn{8}{|c|}{ Welfare quintiles } \\
\hline Q1 & 16.0 & 77.7 & 0.0 & 0.5 & 5.8 & 0.0 & 100.0 \\
\hline Q2 & 22.3 & 69.1 & 0.7 & 2.0 & 5.8 & 0.0 & 100.0 \\
\hline Q3 & 18.1 & 68.1 & 5.4 & 4.3 & 4.1 & 0.0 & 100.0 \\
\hline Q4 & 23.2 & 68.1 & 0.8 & 5.1 & 2.8 & 0.0 & 100.0 \\
\hline Q5 & 27.1 & 63.2 & 0.4 & 3.2 & 4.1 & 2.1 & 100.0 \\
\hline Kampala & 22.1 & 68.2 & 1.5 & 3.3 & 4.3 & 0.6 & 100.0 \\
\hline
\end{tabular}

- Household decisions on where to live are based on the tradeoff between land price and transport costs, particularly time cost of travel. ${ }^{29}$ The better off substitute capital for land when land prices increase, the poor substitute crowding for land price increases. When land prices increase near economic cores of cities and the cost of commuting is high - many people would substitute into the informal land market (slums) rather than be cut off from the labor market. And the cost of developing "public" housing is much higher in places with high land costs. In this context, institutions that increase flexibility of land markets and infrastructure for better urban transport are prerequisites for successful housing interventions.

\section{Prioritizing and sequencing urbanization policies}

\subsection{Spatial and sectoral components of an urbanization strategy}

60. There are two core elements of an urbanization strategy. The first is spatial, where Kampala's size and growth is worrying policymakers concerned with regional inequality and disparities between the more urbanized central region and less urbanized areas. It may be tempting to move businesses into smaller towns and less urbanized areas - but businesses locate in Kampala as they benefit from a range of diverse financial and related services not available elsewhere in the country. Substitutes for Kampala are not Uganda's smaller towns, but other large cities in East Africa. At higher incomes, the economy may be able to provide amenities in more towns and cities, but active efforts to push industries out of Kampala are likely to be counterproductive. In fact, reports of Kampala turning into an "Executive Slum" are a signal of policy neglect, not of city size. For towns at the lower end of the urban portfolio, improvements in agriculture and agro processing will increase demand for their services.

The second is sectoral, where the following are important:

${ }^{29}$ Alonso 1964, Millis 1967 
- Land policies for urban efficiency: Increasing density of economic activities is one of the key features of successful urbanization, enabled by using land for higher value activities over time. Uganda's challenges of encouraging land based transactions include the limited extent of formal tenure security (18\% land is registered and titled), lack of a credible system to value land, and limited incentives for landowners to rent out land. In urban areas, land related constraints are increasing the cost of entry - for instance, it takes 171 days for a business to get a construction permit in Kampala at 1200 times the national per capita income and 77 days to register property.

Planning for infrastructure has become particularly challenging as the 1995 constitution created private land ownership and abolished land leases vested with urban local bodies. Fragmentation of land parcels and rapid suburbanization has ensued, with fiscally starved local governments unable to acquire land and protect rights of way for infrastructure improvements. Priorities for policy include developing a credible system for documenting and valuing land, along with measures to improve urban local bodies finances to acquire land and pay for infrastructure. Options include improving the coverage/ compliance of the property tax, reconsidering transfers from the central government (urban areas only received 3.4\% of total transfers of UGX1.2 trillion to all local governments), and sharing of future oil revenues.

- Basic services for equity: There are large differences in access to basic services such as water, sanitation, and electricity between rural and urban areas. This has adverse consequences for social inclusion as places that have been bypassed by businesses also suffer welfare losses from limited access to public services. Even health services are concentrated in economically prospering places. On the other hand, while education reforms under the UPE have balanced the coverage of primary school enrollments between rural and urban areas, non-completion and deficient proficiency, particularly in rural areas suggest gaps. These portable assets are key for Uganda's rapidly growing and young population.

- Urban transport and mobility: The spatial extent of urban areas and efficiency of the urban economy is reduced with diseconomies from congestion. Well designed urban transport systems that pay attention to user preferences and coordinate with land use planning are likely to help. At current income levels, many motorized transport options are unaffordable for the poor (urban transport fares cost $41 \%$ of incomes for the poorest $20 \%$ of Kampala's population). In fact $70 \%$ of urban workers walk to work. In the short term, it is important to enable the availability of a wide range of service levels / modes at different prices - and invest in sidewalks to reduce pedestrian fatalities in traffic accidents. In the longer term, policies for taxing motor vehicle use (say with gasoline taxes) and supply of public transport choices will be necessary components of a functioning urban area.

- Regional transport for freight movement: The movement of products increases interactions between rural and urban areas and among cities. Recent evidence points out that the cost of interaction is considerably higher along the Kampala - Mombasa corridor (home to most of Uganda's industrial production) relative to Southern Africa or countries such as China, Brazil and the United States. Transport prices are US 8 cents per $\mathrm{km}$ between Mombasa and Kampala, compared with US 6 cents between Durban and Lusaka, US 5 cents in China and 4 cents in the United States. The alternative route through the central corridor is not any cheaper. The bulk of the roads on 2 major corridors (Northern Corridor and Central Corridor) are in good condition. Nonetheless beyond its borders some parts of the corridors are of poor quality and in disrepair, needing infrastructure improvements. This emphasizes the need for regional coordination of transport investments. Furthermore, an effective regulatory regime is needed in a transport system where profit margins go over $85 \%$ for transport operators creating a ridge between transport costs and prices. 
- Housing and slum improvement for livability: Rapid population growth and rural urban migration has generated housing shortages and squalid living conditions in many urban areas. Estimates suggest that 4 million housing units have to be build between now and 2035. Housing policies need to consider (a) tenure choice, where many poor people cannot afford to enter the owner occupied housing market and prefer to be renters - demand for home ownership will increase with incomes, but a range of shelter and tenure options need to be available to urban residents in the short to medium term; and (b) household decisions on where to live are based on the tradeoff between land prices and transport costs, particularly time cost of travel. In fact, when land prices are high, many people will substitute into the informal land market (slums) rather than be cut off from the labor market. Thus, institutions that increase flexibility of land markets and infrastructure for better urban transport are prerequisites for successful housing interventions.

\subsection{Sequencing spatial and sectoral priorities - learning from the 2009 World Development Report framework}

61. Spatial and sectoral components of the strategy can be combined using the policy framework for urbanization developed under the 2009 World Development Report on economic geography. The policy framework focuses on institutions that govern and manage land as well as manage the provision of basic services; infrastructure that improves connectivity within urban areas and between urban areas and their hinterland; and targeted interventions that reduce social and economic divisions. How can institutions, infrastructure and interventions be prioritized and sequenced in Uganda?

- For rural areas and small towns that dominate the country's landscape (and where urbanization is incipient) - the policies should encourage economic density by focusing on institutions that make land markets flexible and extend basic services.

- For medium sized cities (with more than 50,000 people), the focus should be on encouraging economic density as well as on connectivity. Land use planning institutions should set aside (and protect) rights of way to guide urban form and develop infrastructure, as well link these plans with future transport improvements. Connective infrastructure to improve mobility is important including setting and enforcing safety standards along with managing heterogeneous types of transport providers. As many residents use non motorized transport, planning for sidewalks will help reduce risk to pedestrians. Institutions and infrastructure are priorities at this stage of urbanization.

- For the country's largest metropolis - Kampala, the policy challenges are more complex. Rapid spatial expansion - while a natural process - will necessitate coordinated policy and planning efforts between Kampala city and neighboring jurisdictions. While annexation and centralized management have been proposed as options for managing the metropolis, international evidence suggests that there are alternative models of service delivery in metropolitan settings that merit consideration. Transport improvements become critical at this time to connect the expanding city and spatially integrate labor markets. Investments in busways should be considered, along with options for reducing use of private vehicles. In addition, targeted interventions will be needed to improve the housing stock, but these need to be preceded by improvements in land use institutions and transport infrastructure. 


\subsubsection{Box 5: The jury is still out on appropriate models for managing expanding metropolitan areas}

Kampala is rapidly expanding. Originally planned for 350,000 people, estimates suggest that today it is home to about 2.5 million people with an additional 1 million commuters who come to the city during the day. How should such an expanding metropolis be managed and who should be responsible? The 2005 Constitutional Amendment of $2005^{1}$ declared Kampala as the Capital City of Uganda would be administered by the Central Government, and subsequently, a Kampala Capital City Authority has been established to govern the City as well as the creation of a Metropolitan Physical Planning Authority, responsible for developing a Metropolitan Authority Structure and Development Plan for the capital city and the metropolitan area. How Kampala is managed and governed is a critical question as the city is the driver of economic prosperity for the country. And urban governance structures matters as they affect the quantity, quality, and efficiency of services, and determine whether costs are shared throughout the metropolitan areas in a fair and efficient way.

Metropolitan wide coordination in service delivery matters for transportation (coordination across municipal boundaries), water (determine where treatment facilities will be located), solid waste (determine where garbage disposal sites will be located), policing (crime spills across municipal boundaries), and social services, health and education (decisions on levels of expenditures and cost sharing). To address coordination, several metropolitan governance models exist around the world:

- One tier government model (fragmented local government)

- One-tier government model (consolidated local governments through annexation or amalgamation)

- Two-tier government model

- Voluntary cooperation (incl. special purpose districts)

Researchers have identified several criteria to evaluate alternate models of governance: (a) Efficiency Ability to achieve economies of scale, and ability to reduce negative spillovers (externalities) across local boundaries; (b) Equity: ability to share costs and benefits of services fairly across the metropolitan area, (c) Accessibility and accountability for decision-making; and (d) Local responsiveness/competition. Studies across metropolitan areas highlight that governance models evolve over time (Toronto, Cape Town, Abidjan, Cape Town) and consolidation does not necessarily reduce costs (as in Toronto). However, neither theory nor practice tells us clearly which model of governance is best for large metropolitan areas. 


\section{References}

Alonso, W. (1964). “Location and Land Use,” Harvard University Press (Massachusetts)

Angel (2010). Preparing for a planet of cities

Frank Byamugisha (2010). Land Markets, Factor Mobility and Regional Economic Integration in Uganda. Background paper prepared for this report

Deininger, Klaus \& Castagnini, Raffaella, (2006). "Incidence and impact of land conflict in Uganda," Journal of Economic Behavior \& Organization, Elsevier, vol. 60(3), pages 321-345, July.

Deininger, Klaus \& Jin, Songqing, (2003). "The Impact of Property Rights on Households' Investment, Risk Coping, and Policy Preferences: Evidence from China," Economic Development and Cultural Change, University of Chicago Press, vol. 51(4), pages 851-82, July.

Deininger, Klaus. (2003). "Causes and consequences of civil strife: micro-level evidence from Uganda." Oxford Economic Papers, 55, pp. 579-606.

Dutz, M., A. Hayri, and P. Ibarra (2000), "Regulatory Reform, Competition, and Innovation: A Case Study of the Mexican Road Freight Industry," World Bank Policy Research Working Papers, No. 2318.

Ellison, Glenn \& Glaeser, Edward L, 1997. "Geographic Concentration in U.S. Manufacturing Industries: A Dartboard Approach," Journal of Political Economy, University of Chicago Press, vol. 105(5), pages 889-927, October

Gilles Duranton \& Henry G. Overman, (2008). "Exploring The Detailed Location Patterns Of U.K. Manufacturing Industries Using Microgeographic Data," Journal of Regional Science, Wiley Blackwell, vol. 48(1), pages 213-243.

Glenn Ellison \& Edward L. Glaeser, (1999). "The Geographic Concentration of Industry: Does Natural Advantage Explain Agglomeration?," American Economic Review, American Economic Association, vol. 89(2), pages 311-316, May.

Kajuna 2011

Klaus Deininger, (2003). "Land Markets in Developing and Transition Economies: Impact of Liberalization and Implications for Future Reform," American Journal of Agricultural Economics, American Agricultural Economics Association, vol. 85(5), pages 1217-1222, December.

Lall, Somik V. \& Schroeder, Elizabeth \& Schmidt, Emily, (2009). "Identifying spatial efficiency-equity tradeoffs in territorial development policies : evidence from Uganda," Policy Research Working Paper Series 4966, The World Bank.

\section{LSE paper}

Millis 1967 
Nyakaana, J. B., H. Sengendo, et al. (2004). "Urban Development, Population and the Environment in Uganda: The Case of Kampala City and its Environs". Kampala.

Martin Onyach-Olaa, Martin (2010). Urbanization - Issues for Inclusive Growth. Background paper prepared for this report

Olivier Boylaud \& Giuseppe Nicoletti, (2001). "Regulation, market structure and performance in telecommunications," OECD Economic Studies, OECD Publishing, vol. 2001(1), pages 4.

Özden, Çağlar, and Jinu Koola. 2010. "Role of Emigration and Emigrant Networks in Labor Market Decisions of Non-Migrants. " In Annual World Bank Conference on Development Economics 2009: People, Politics, and Globalization, ed. Justin Yifu Lin and Boris Pleskovic. Washington, DC: World Bank.

Park, J., D. Kim, Y. Ko, E. Kim, K. Park, K. Kim (2011), Urbanization and Urban Policies in Korea, Korea Research Institute for Human Settlements.

Paul Collier \& Anthony J. Venables, (2007). "Rethinking Trade Preferences: How Africa Can Diversify its Exports," The World Economy, Wiley Blackwell, vol. 30(8), pages 1326-1345, 08.

Paul Mukwaya, Yazidhi Bamutaze, Samuel Mugarura, and Todd Benson (2001). "Rural-Urban Transformation In Uganda". IFPRI, Working Paper

Raballand, G and P. Macchi (2009) Transport Prices and Costs - The Need to Revisit Donors' Policies in Transport in Africa.

Smith, N. G., Goldstein, D. L. and Bartholomew, G. A. (1986). "Is long-distance migration possible for soaring hawks using only stored fat?," Auk 103: 607-611.

Uchida, H., and A. Nelson. (2008). Agglomeration index: Towards a new measure of urban concentration. Background paper to World Development Report 2009: Reshaping economic geography. Washington, DC: World Bank.

Uganda Bureau of Statistics (UBOS), (2006). "Uganda National Household Survey 2005/06: Report on the Socio-Economic Module,” Kampala: UBOS.

Uganda Bureau of Statistics (UBOS), (2010). “Statistical Abstract 2010,” Kampala: UBOS.

United Nations (2009). "World Urbanization Prospects: The 2009 Revision Population Database", United Nations Population Division (CD-ROM). http://esa.un.org/unpd/wup/index.htm

World Bank (2011) Demography and Economic Growth in Uganda. draft

World Bank. (2008). WDR2009: Reshaping Economic Geography. Oxford University Press.

World Bank. (2009). “World Development Indicators (CD-ROM),” Washington, DC: World Bank. 


\section{Statistical Annex}
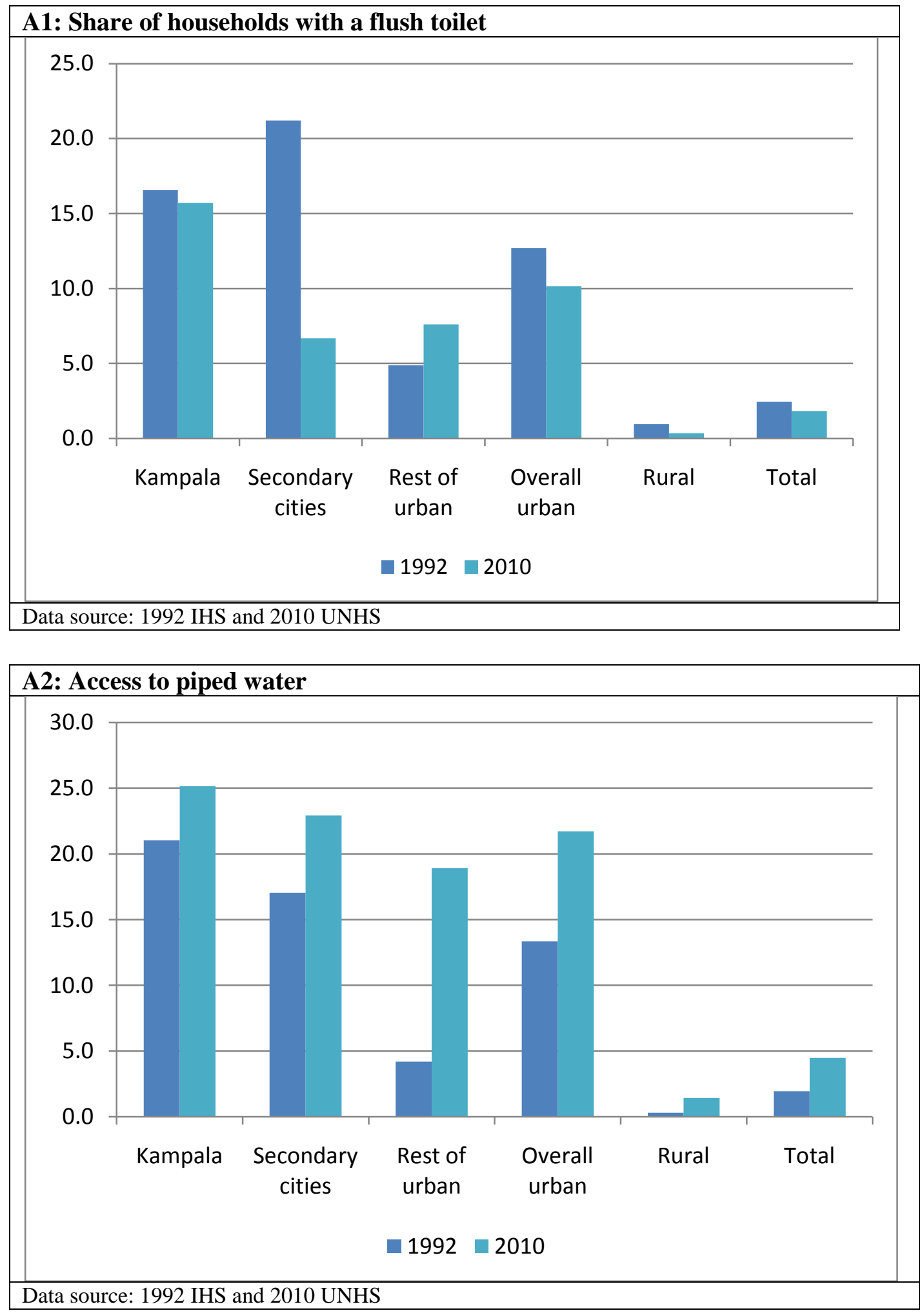

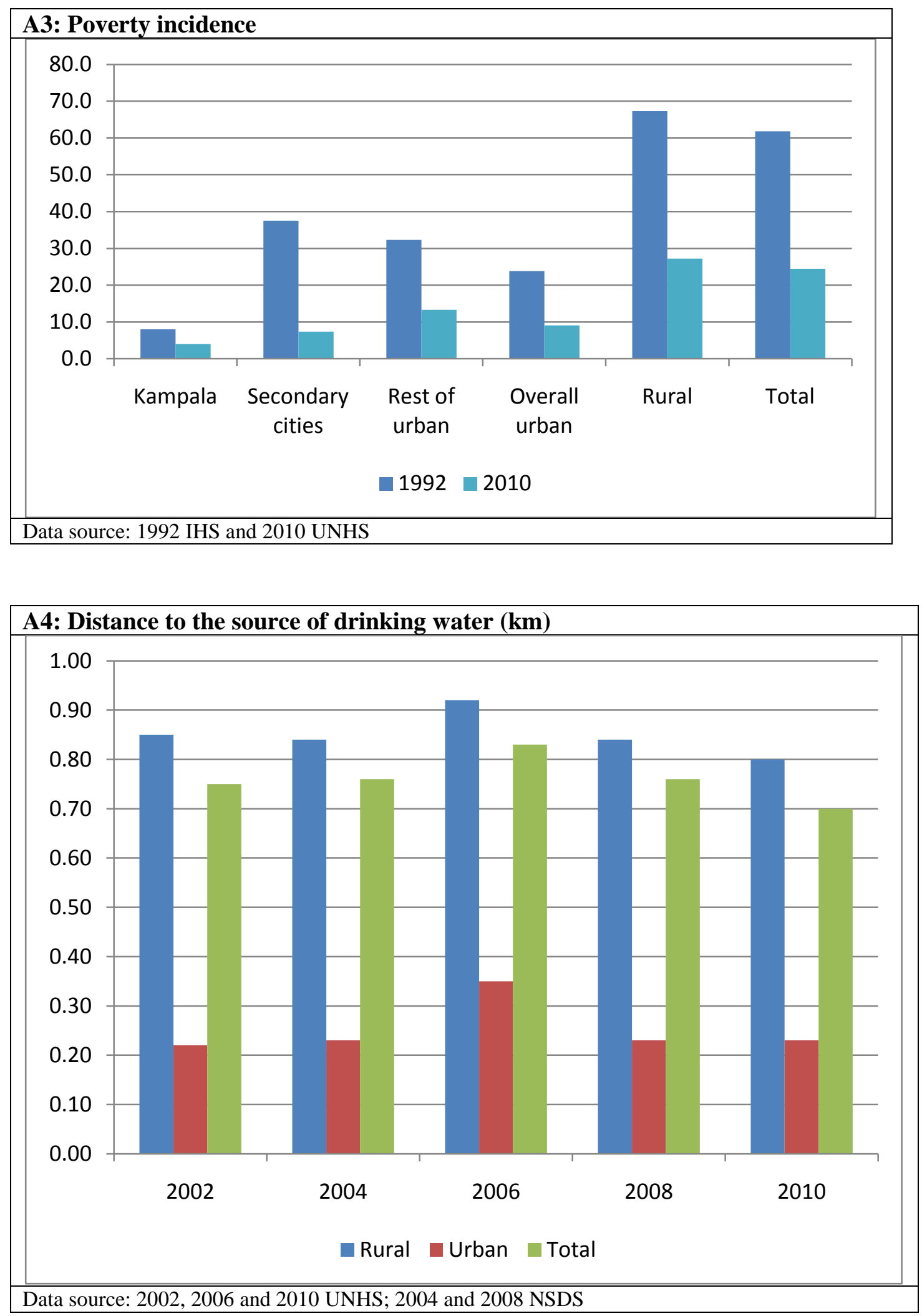

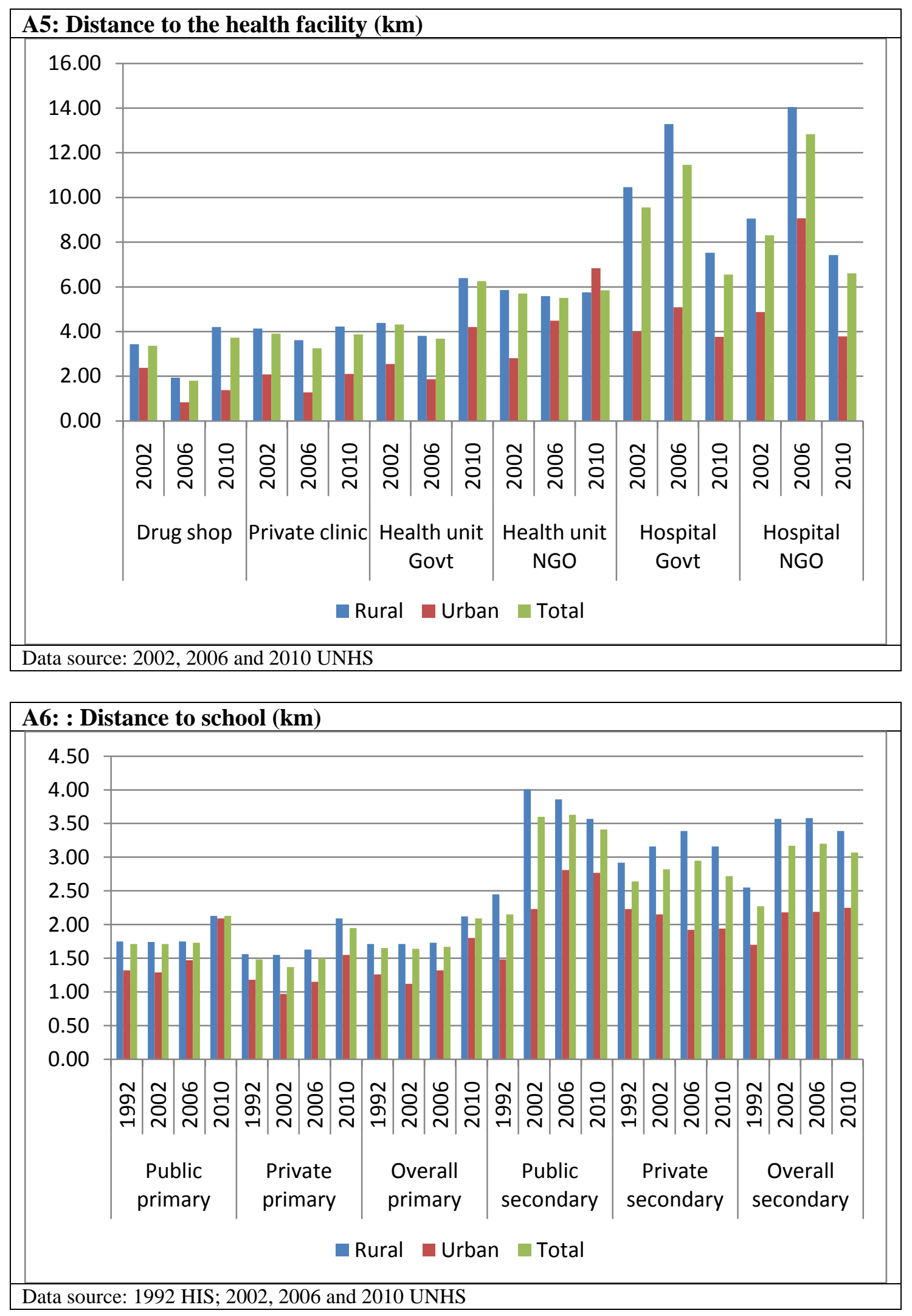


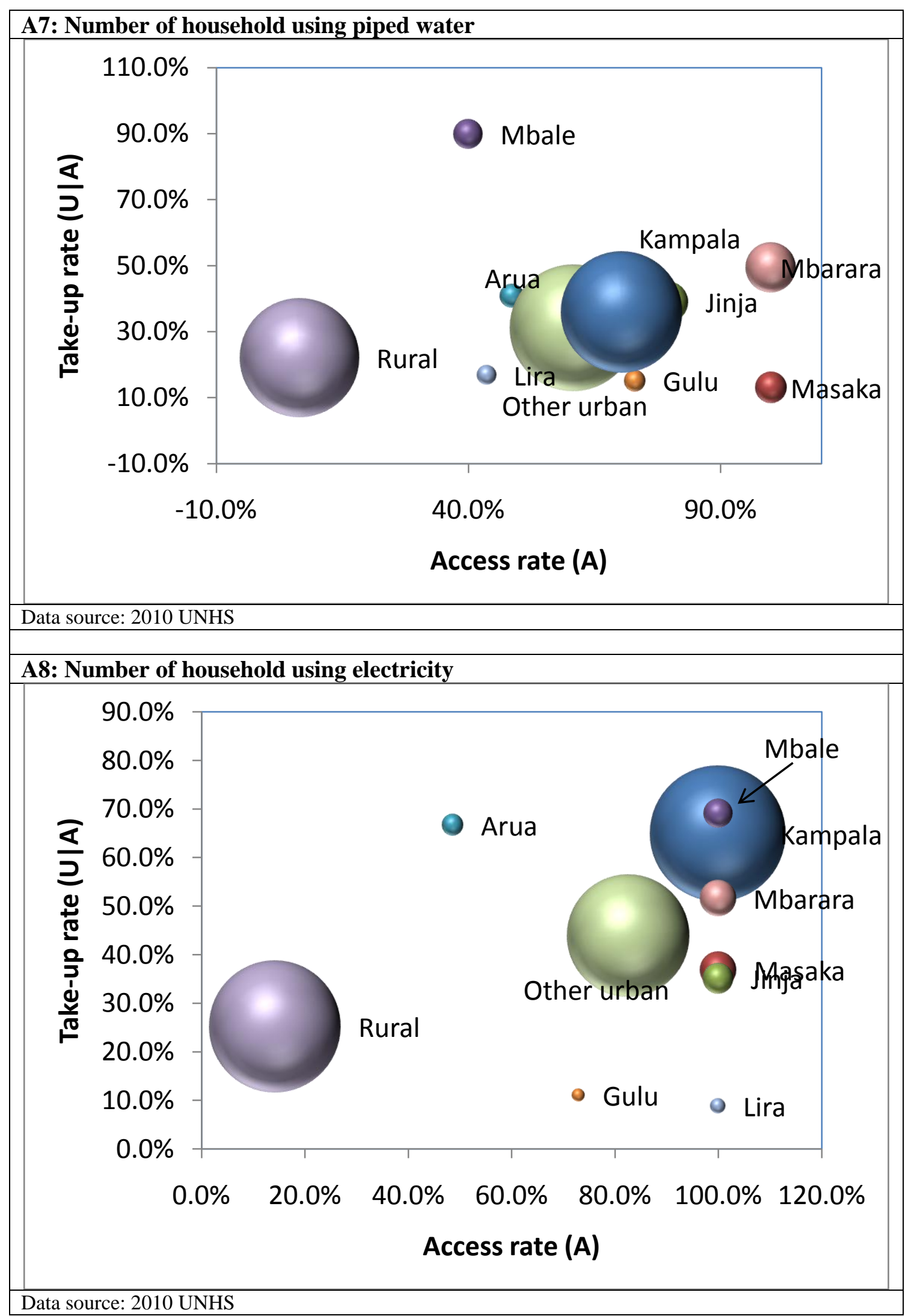



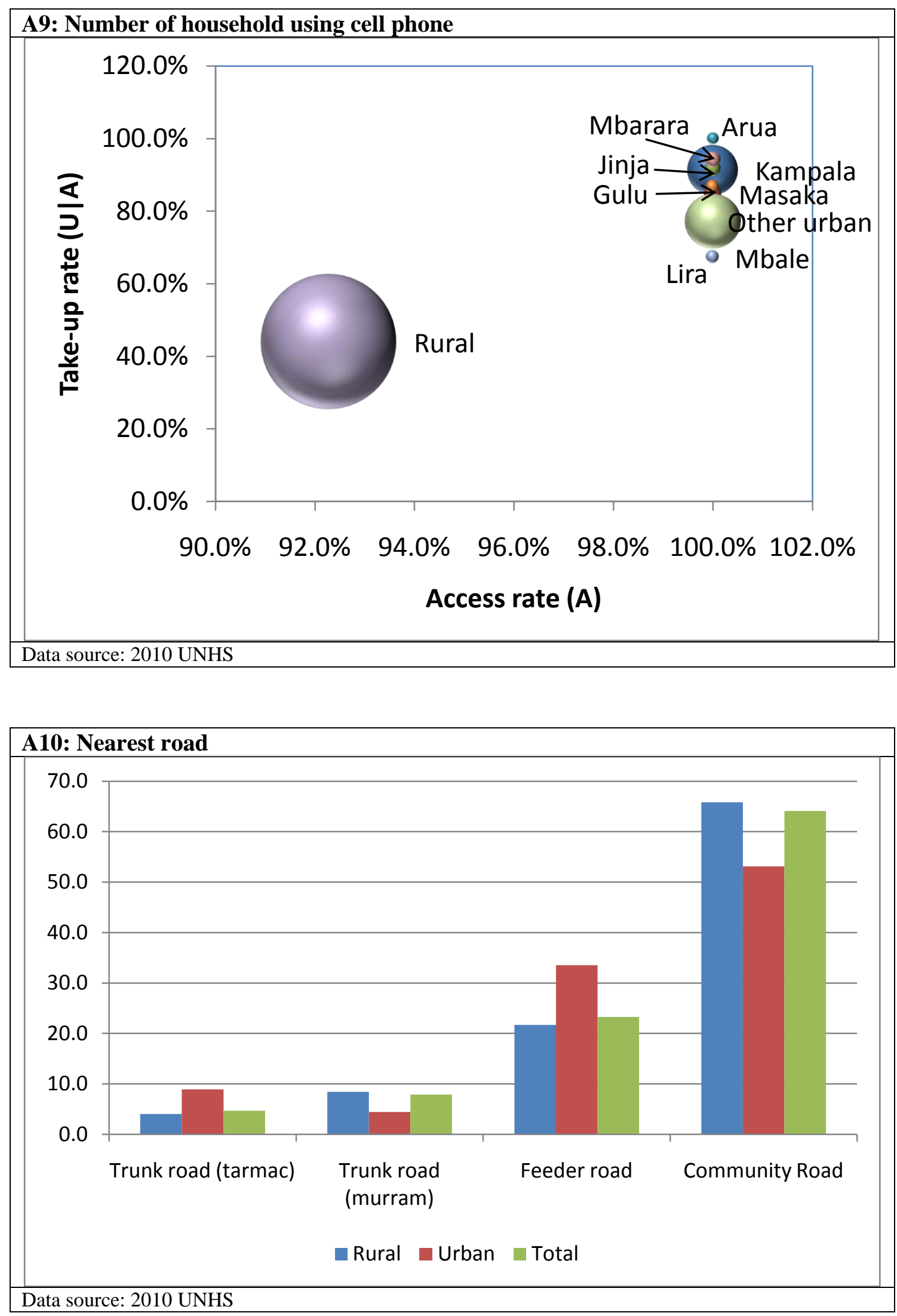

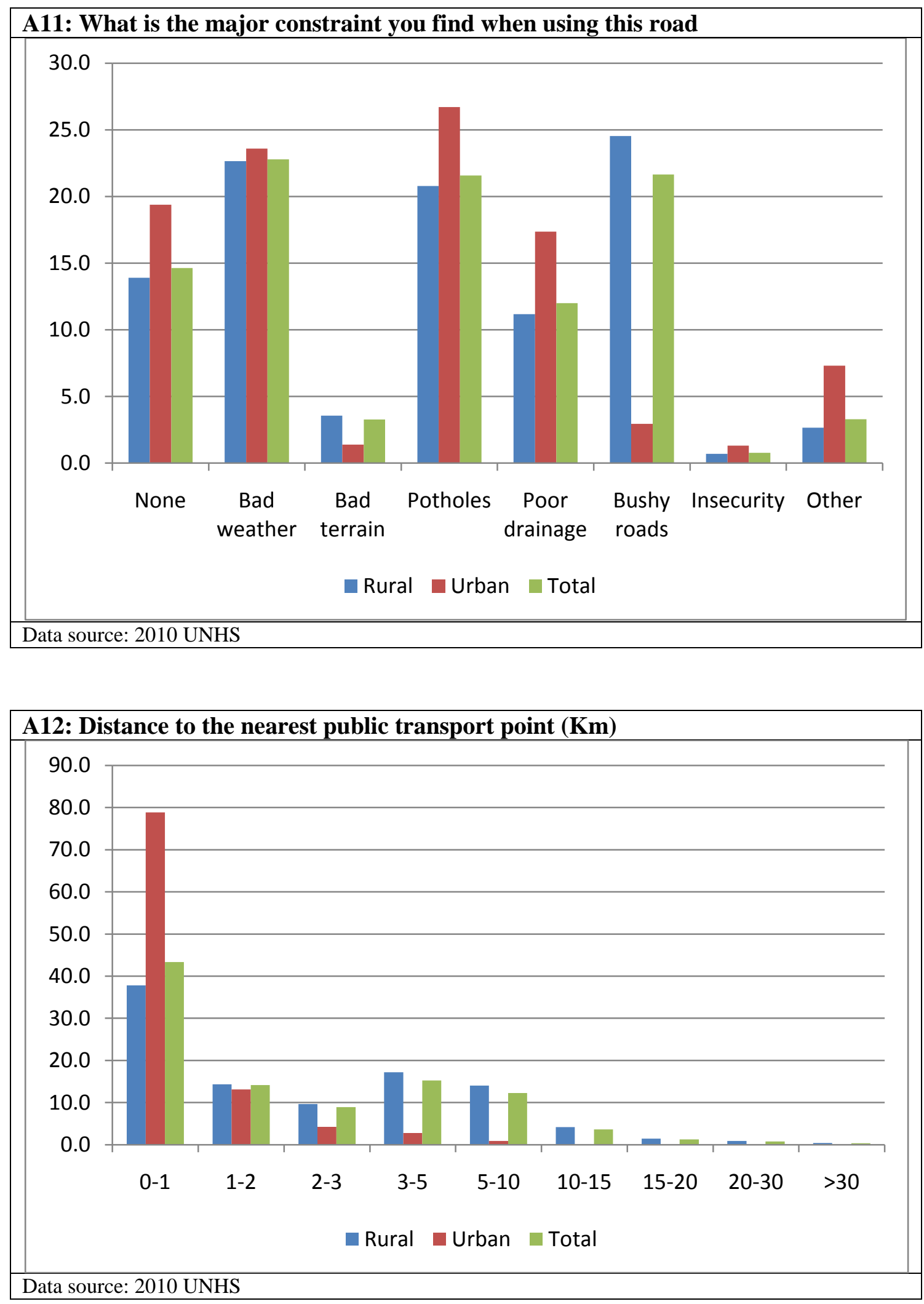


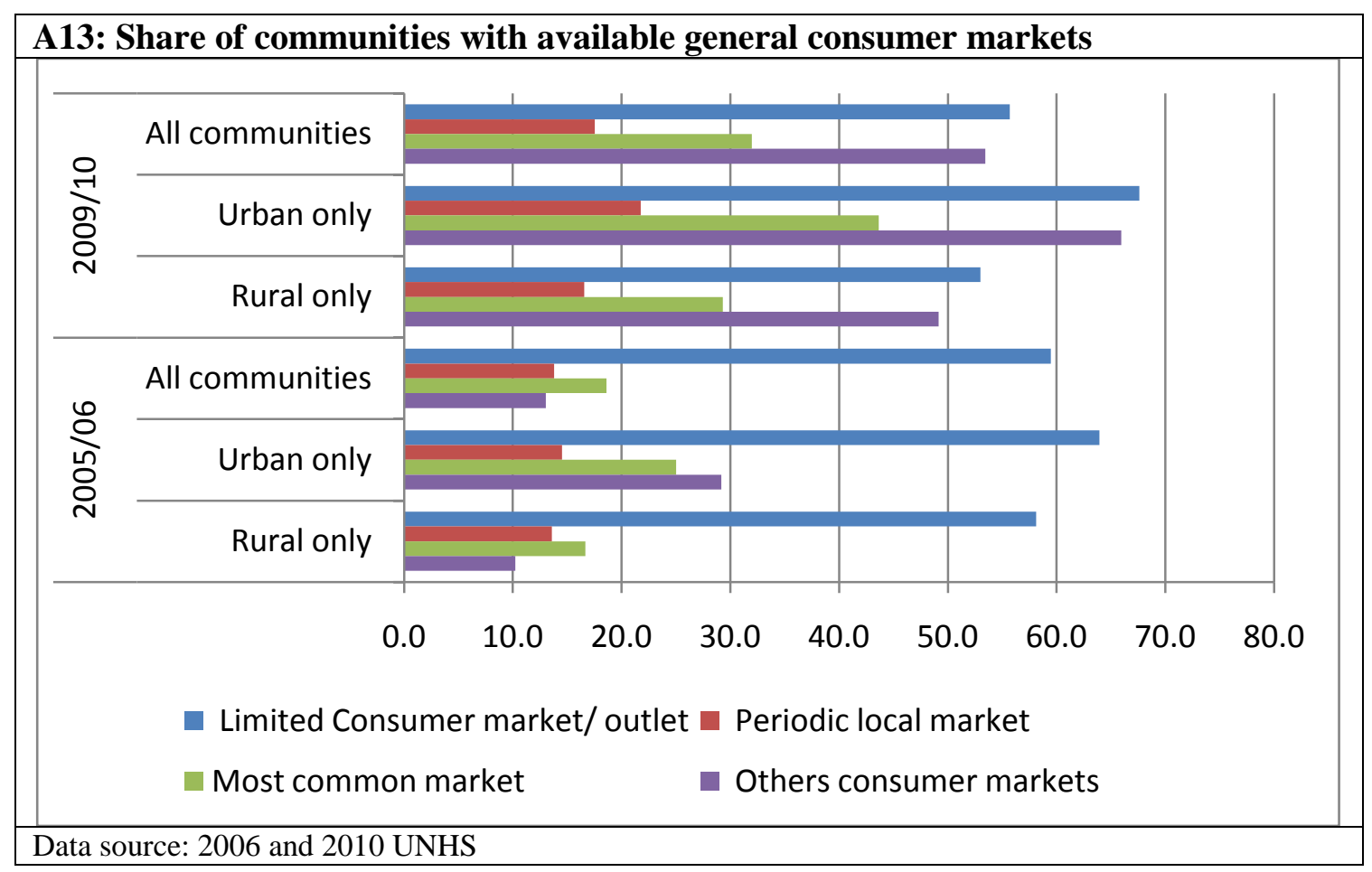

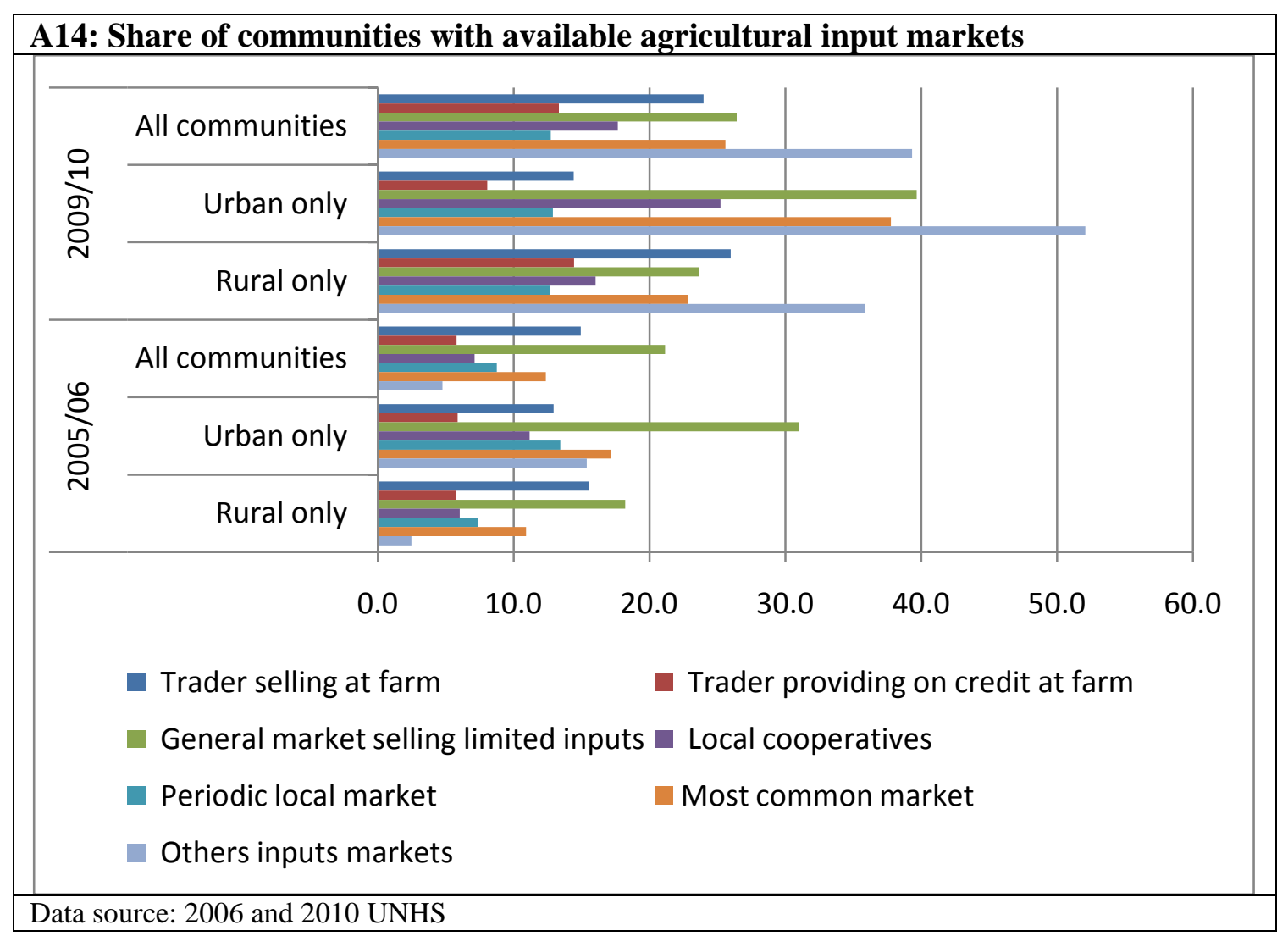



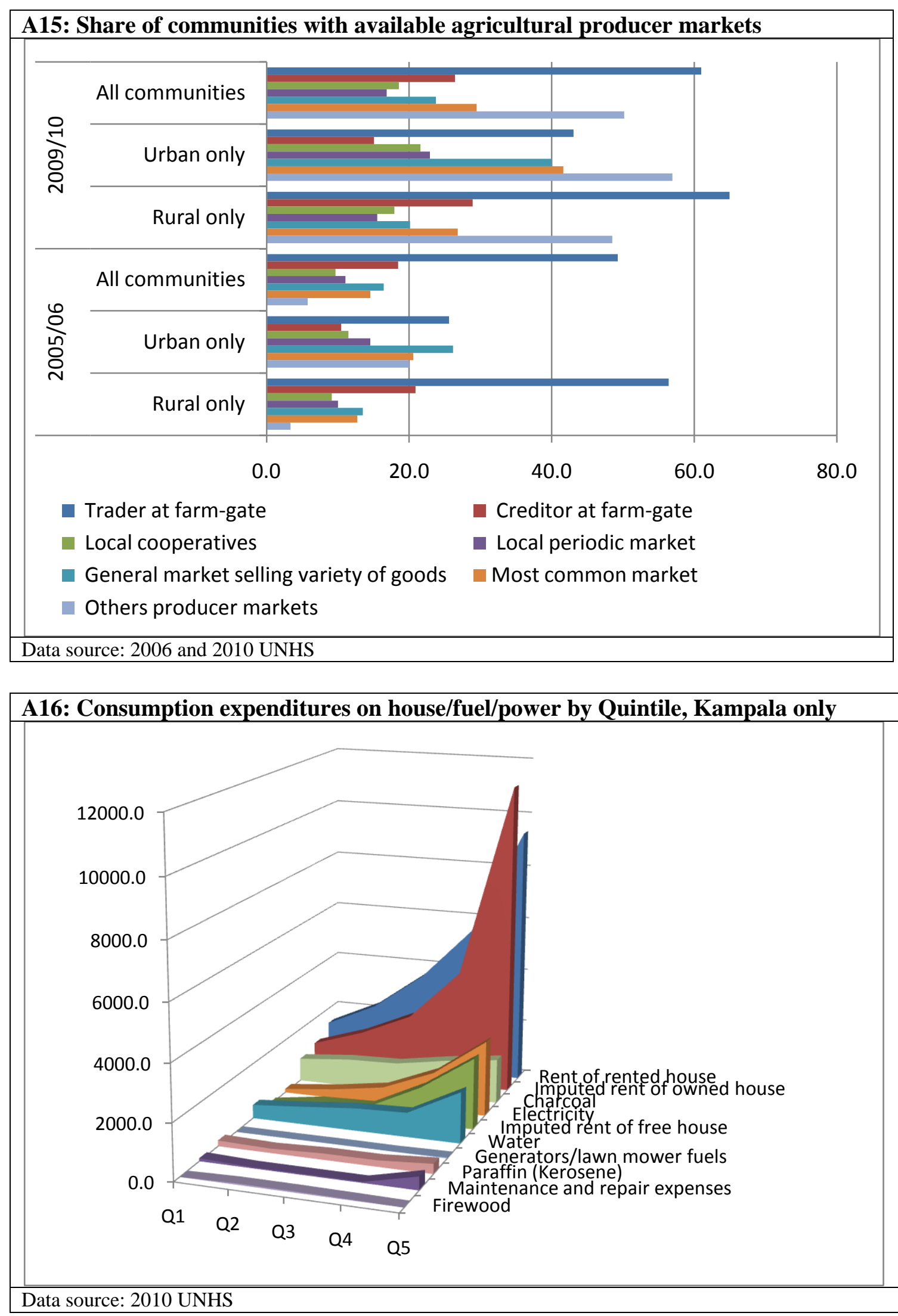


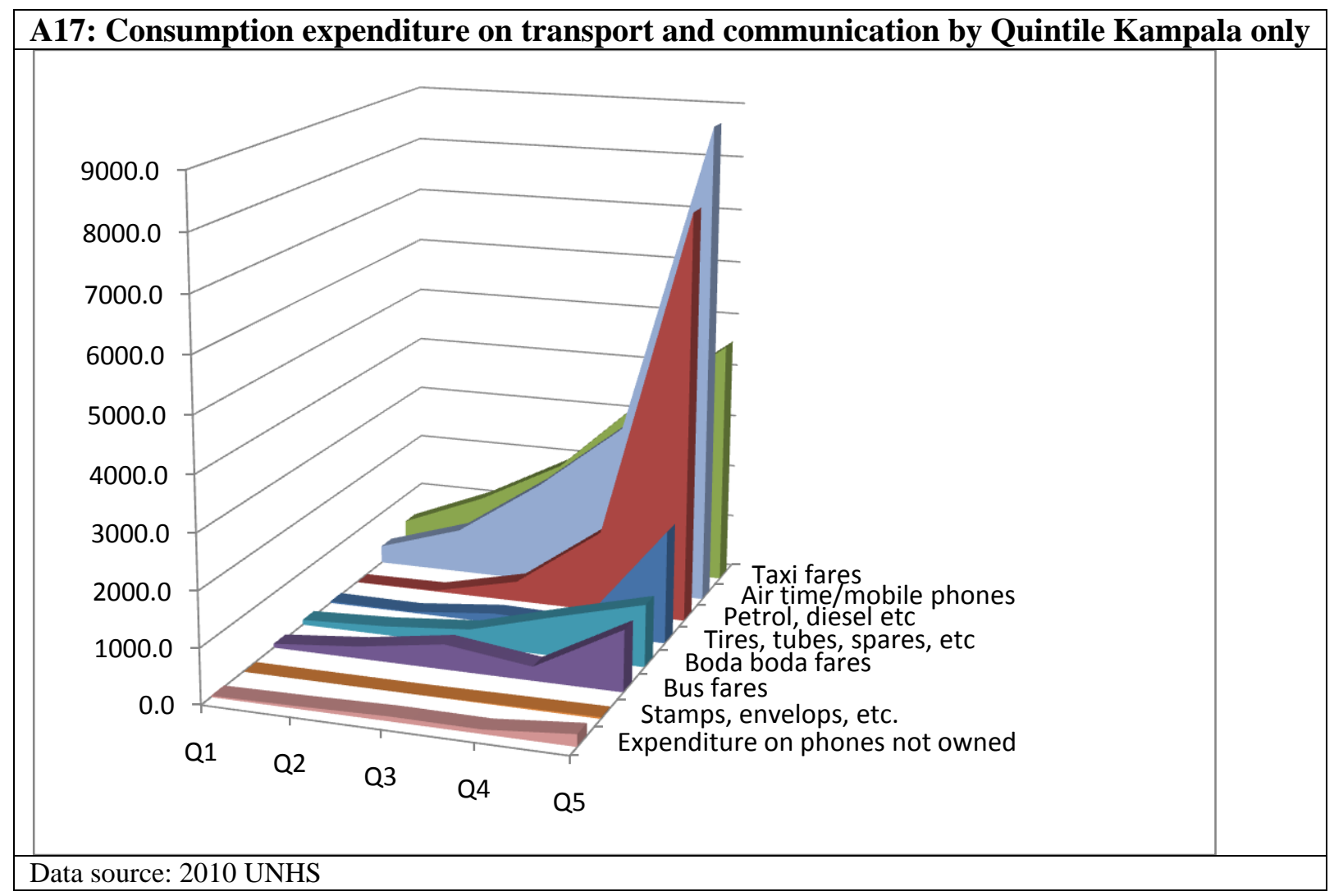




\begin{tabular}{|rlrc|}
\hline A18: 25 Largest Cities in Uganda (2011 Estimates) & \\
\hline Rank & Name & 2011 Population Estimate & Share in total urban pop $(\%)$ \\
\hline 1 & Kampala & $1,659,600$ & 34.2 \\
2 & Kira & 179,800 & 3.7 \\
3 & Gulu & 154,300 & 3.2 \\
4 & Lira & 108,600 & 2.2 \\
5 & Mbale & 91,800 & 1.9 \\
6 & Nansana & 89,900 & 1.8 \\
7 & Jinja & 89,700 & 1.8 \\
8 & Mbarara & 83,700 & 1.7 \\
9 & Entebbe & 79,700 & 1.6 \\
10 & Kasese & 74,300 & 1.5 \\
11 & Masaka & 74,100 & 1.5 \\
13 & Soroti & 66,000 & 1.4 \\
12 & Njeru & 64,900 & 1.3 \\
14 & Arua & 59,400 & 1.2 \\
15 & Kitgum & 59,700 & 1.2 \\
16 & Mukono & 59,000 & 1.2 \\
17 & Iganga & 53,700 & 1.1 \\
18 & Koboko & 51,300 & 1.1 \\
19 & Busia & 47,100 & 1.0 \\
20 & Fort Portal & 47,100 & 1.0 \\
21 & Kabale & 44,600 & 0.9 \\
22 & Masindi & 45,400 & 0.9 \\
23 & Tororo & 43,700 & 0.9 \\
24 & Hoima & 42,600 & 0.9 \\
25 & Mityana & 39,300 & 0.8 \\
& Other urban & $1,450,200$ & 29.8 \\
Total & urban & & \\
Data source: UBOS & & \\
& & & \\
\hline
\end{tabular}




\begin{tabular}{|c|c|c|}
\hline \multicolumn{3}{|l|}{ A19: Herfindhal concentration index } \\
\hline & \multicolumn{2}{|c|}{ Herfindhal } \\
\hline & \#Firms & Employment \\
\hline Agriculture & 0.3769 & 0.2287 \\
\hline Community, Social and Personal Services & 0.1844 & 0.4295 \\
\hline Construction & 0.2657 & 0.6610 \\
\hline Education & 0.3459 & 0.4370 \\
\hline Electricity, Gas \& Water & 0.5556 & 0.9723 \\
\hline Finance \& Insurance & 0.3971 & 0.8840 \\
\hline Fishing & 1.0000 & 1.0000 \\
\hline Health & 0.1459 & 0.1756 \\
\hline Hotels \& Restaurants & 0.1177 & 0.1898 \\
\hline Manufacturing & 0.1545 & 0.2283 \\
\hline Mining \& Quarrying & 0.5062 & 0.4426 \\
\hline NGO & 0.7222 & 0.6070 \\
\hline Post and Telecommunications & 0.7098 & 0.9900 \\
\hline Public Administration and Defence & 0.3877 & 0.8463 \\
\hline Real Estate \& Business Services & 0.3085 & 0.7557 \\
\hline Social Work Activities & 0.2774 & 0.3675 \\
\hline Trade & 0.2179 & 0.3790 \\
\hline Transport & 0.4579 & 0.7307 \\
\hline Total & 0.1930 & 0.2812 \\
\hline
\end{tabular}

\begin{tabular}{|lcc|}
\hline A20: Kampala's population by division \\
\hline & Population & Share $(\%)$ \\
Central Division & 122,900 & 7.4 \\
Kawempe Division & 365,900 & 22.0 \\
Makindye Division & 423,100 & 25.5 \\
Nakawa Division & 335,700 & 20.2 \\
Rubaga Division & 411,900 & 24.8 \\
Kampala District & $1,659,500$ & 100.0 \\
\hline \multicolumn{2}{|l}{ Data source: UBOS (2010) } \\
\hline
\end{tabular}




\begin{tabular}{|c|c|c|}
\hline \multicolumn{3}{|c|}{ A21: Kampala's parish with more than 25000 people } \\
\hline Parish & Population & Share $(\%)$ \\
\hline Kasubi & 60,900 & 3.67 \\
\hline Mutungo & 60,300 & 3.63 \\
\hline Kawempe I & 50,800 & 3.06 \\
\hline Lubia & 48,600 & 2.93 \\
\hline Kyebando & 46,100 & 2.78 \\
\hline Nsambya Central & 42,200 & 2.54 \\
\hline Kabowa & 39,600 & 2.39 \\
\hline Mutundwe & 37,600 & 2.27 \\
\hline Naguru II & 36,400 & 2.19 \\
\hline Nateete & 33,300 & 2.01 \\
\hline Kibuye I & 32,600 & 1.96 \\
\hline Kibuli & 31,600 & 1.90 \\
\hline Busega & 31,300 & 1.89 \\
\hline Rubaga & 29,100 & 1.75 \\
\hline Bukoto II & 29,100 & 1.75 \\
\hline Ggaba & 28,200 & 1.70 \\
\hline Nakulabye & 27,600 & 1.66 \\
\hline Bukasa & 27,500 & 1.66 \\
\hline Lungujja & 27,100 & 1.63 \\
\hline Mbuya I & 26,300 & 1.58 \\
\hline Kansanga - Muyenga & 26,300 & 1.58 \\
\hline Kanyanya & 26,200 & 1.58 \\
\hline Bukoto I & 25,200 & 1.52 \\
\hline Wabigalo & 25,100 & 1.51 \\
\hline Bwaise I & 25,100 & 1.51 \\
\hline Total main parish & 874,100 & 52.67 \\
\hline Other parish & 785,400 & 47.33 \\
\hline Total & $1,659,500$ & 100.00 \\
\hline
\end{tabular}

